\title{
Contribution of picoplankton to the total particulate organic carbon concentration in the eastern South Pacific
}

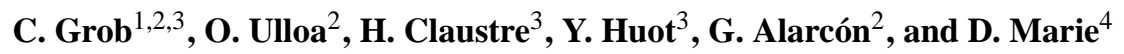 \\ ${ }^{1}$ Graduate Programme in Oceanography, Universidad de Concepción, Concepción, Chile \\ ${ }^{2}$ Department of Oceanography and Center for Oceanographic Research in the eastern South Pacific, Universidad de \\ Concepción, Casilla 160-C, Concepción, Chile \\ ${ }^{3}$ CNRS, Laboratoire d'océanographie de Villefranche, 06230 Villefranche-sur-Mer, France; Université Pierre et Marie \\ Curie-Paris 6, Laboratoire d'océanographie de Villefranche, 06230 Villefranche-sur-Mer, France \\ ${ }^{4}$ Station Biologique, CNRS, INSU et Université Pierre et Marie Curie, 29482 Roscoff Ceder, France
}

Received: 27 February 2007 - Published in Biogeosciences Discuss.: 9 May 2007

Revised: 6 August 2007 - Accepted: 1 October 2007 - Published: 15 October 2007

\begin{abstract}
Prochlorococcus, Synechococcus, picophytoeukaryotes and bacterioplankton abundances and contributions to the total particulate organic carbon concentration, derived from the total particle beam attenuation coefficient $\left(c_{\mathrm{p}}\right)$, were determined across the eastern South Pacific between the Marquesas Islands and the coast of Chile. All flow cytometrically derived abundances decreased towards the hyper-oligotrophic centre of the gyre and were highest at the coast, except for Prochlorococcus, which was not detected under eutrophic conditions. Temperature and nutrient availability appeared important in modulating picophytoplankton abundance, according to the prevailing trophic conditions. Although the non-vegetal particles tended to dominate the $c_{\mathrm{p}}$ signal everywhere along the transect (50 to 83\%), this dominance seemed to weaken from oligo- to eutrophic conditions, the contributions by vegetal and non-vegetal particles being about equal under mature upwelling conditions. Spatial variability in the vegetal compartment was more important than the non-vegetal one in shaping the water column particle beam attenuation coefficient. Spatial variability in picophytoplankton biomass could be traced by changes in both total chlorophyll $a$ (i.e. mono + divinyl chlorophyll a) concentration and $c_{\mathrm{p}}$. Finally, picophytoeukaryotes contributed $\sim 38 \%$ on average to the total integrated phytoplankton carbon biomass or vegetal attenuation signal along the transect, as determined by size measurements (i.e. equivalent spherical diameter) on cells sorted by flow cytometry and optical theory. Although there are some uncertainties as-
\end{abstract}

Correspondence to: $\mathrm{C}$. Grob

(mgrob@profc.udec.cl) sociated with these estimates, the new approach used in this work further supports the idea that picophytoeukaryotes play a dominant role in carbon cycling in the upper open ocean, even under hyper-oligotrophic conditions.

\section{Introduction}

Global estimates indicate that about half of the Earth's primary production (PP) takes place in the ocean (Field et al., 1998). Of a mean global marine PP of $50.7 \mathrm{Gt} \mathrm{C}$ $\mathrm{y}^{-1}$ estimated through ocean-colour-based models (Carr et al., 2006), 86\% would occur in the open ocean (Chen et al., 2003). Here the photosynthetic biomass is dominated by three main picophytoplanktonic $(<2-3 \mu \mathrm{m})$ groups (e.g. Li, 1995): cyanobacteria of the genera Prochlorococcus (Chisholm et al., 1988) and Synechococcus (Waterbury et al., 1979), and eukaryotes belonging to diverse taxa (Moon-van der Staay et al., 2001).

Although cyanobacteria, especially Prochlorococcus (Li and Wood, 1988; Chisholm et al., 1988), tend to dominate in terms of numerical abundance, it has been shown that eukaryotic phytoplankton (usually $<3.4 \mu \mathrm{m}$ ) dominates the ultraplankton $(<5 \mu \mathrm{m})$ photosynthetic biomass in the northern Sargasso Sea ( $\mathrm{Li}$ et al., 1992) and in the eastern Mediterranean Sea (Li et al., 1993). Across the North and South Atlantic Subtropical Gyres (Zubkov et al., 1998, 2000) and eastern South Pacific (Grob et al., 2007) picophytoeukaryotes also constituted a considerable fraction of the picophytoplanktonic carbon biomass.

Published by Copernicus Publications on behalf of the European Geosciences Union. 
Using flow cytometry cell sorting combined with ${ }^{14} \mathrm{C}$ measurements, Li (1994) made the only simultaneous groupspecific primary production rates measurements available so far in the literature for Prochlorococcus, Synechococcus and picophytoeukaryotes. Even though he could only apply this methodology at three different stations in the North Atlantic Ocean and at a single depth per station, this author's results showed that picophytoeukaryotes contribution to picophytoplankton primary production increased as the Prochlorococcus to picophytoeukrayotes abundances ratio decreased. At a coastal Pacific site in the Southern California Bight, on the other hand, Worden et al. (2004) reported that picophytoeukaryotes had the highest picophytoplankton growth rates and contributions to the net community production and carbon biomass on annual bases.

Picophytoeukaryotes can therefore make a significant contribution to the picophytoplanktonic PP and carbon biomass (see above). Carbon being the universal currency in marine ecological modelling, looking inside the pico-autotrophic "black box" to determine the distribution of carbon biomass among the different groups becomes fundamental to better understand the respective role of these groups in the global carbon cycle. Recent biogeochemical models have made a significant step forward on this subject by incorporating not only different plankton functional types, but also different groups within these functional types (e.g. cyanobacteria, picophytoeukaryotes, nitrogen fixers) in order to reproduce some of the ecosystem's variability (e.g. Bisset et al., 1999; Le Quéré et al., 2005). Different picophytoplanktonic groups have different physiological characteristics such as optimal specific rates of photosynthesis, adaptation to light, photosynthetic efficiencies and maximum specific growth rates (Veldhuis et al., 2005, and references therein). Knowing where one group dominates over the others could therefore help choosing the appropriate physiological parameters to estimate PP from surface chlorophyll $a$ concentrations retrieved from space and improve such estimates at the large scale.

The measurement of the particle beam attenuation coefficient $\left(c_{\mathrm{p}}\right)$ has proven to be a very powerful tool in determining particle load and particulate organic carbon (POC) concentrations at the global (e.g. Gardner, 2006) as well as at the regional scale (e.g. Claustre et al., 1999; Oubelkheir et al., 2005). High frequency measurements of $c_{\mathrm{p}}$ signal can also be used to derive rates of change in particulate organic stocks like gross and net community production (Claustre et al., 2007). In situ $c_{\mathrm{p}}$ profiles associated with the simultaneous cytometric determination of the different phytoplanktonic groups and bacterioplankton (Bacteria + Archaea) abundances have the potential to allow the estimation of the contribution of these groups to the bulk $c_{\mathrm{p}}$, and hence to POC. Group-specific contributions to POC can therefore be estimated from their contributions to $c_{\mathrm{p}}$. In the equatorial Pacific, for instance, picophytoeukaryotic cells would dominate the vegetal contribution to $c_{\mathrm{p}}$ (Chung et al., 1996; DuRand and Olson, 1996; Claustre et al., 1999). These estimations require however that the mean cell size and refractive index of each group are known or at least assumed (Claustre et al., 1999, and references therein). Total and group-specific beam attenuation coefficients can be obtained at relatively short time scales, but also have the advantage of being amenable to large scale in situ surveys on carbon stocks and cycling, and even to global estimation, since bulk oceanic bio-optical properties can be retrieved from space (e.g. Gardner, 2006).

In the present work we tried to answer the following questions: (1) What is the contribution of the different picoplanktonic groups to POC in the upper ocean? and (2) How does the spatial variability in these group's contributions influence the spatial changes in POC in the upper ocean? For this, we studied the waters of the eastern South Pacific, which present an extreme gradient in trophic conditions, from the hyper-oligotrophic waters of the central gyre to the eutrophic coastal upwelling waters off South America. Using flow cytometry cell sorting we were able to isolate different picophytoplankton populations in situ to obtain their mean cell sizes (as equivalent spherical diameters), which allowed us to improve estimations on the group-specific attenuation coefficients, and therefore on group-specific contributions to POC.

\section{Methods}

A total of 24 stations were sampled between the Marquesas Islands $\left(\sim 8.4^{\circ} \mathrm{S} ; 141.2^{\circ} \mathrm{W}\right)$ and the coast of Chile $\left(\sim 34.6^{\circ} \mathrm{S} ; 72.4^{\circ} \mathrm{W}\right)$ during the French expedition BIOSOPE (BIogeochemistry and Optics SOuth Pacific Experiment) in austral spring time (26 October to 11 December 2004) (Fig. 1). Temperature, salinity and oxygen profiles were obtained with a conductivity-temperature-depth-oxygen profiler (CTDO, Seabird 911 Plus). Nutrient concentrations (nitrate, nitrite, ammonium, phosphate and silicate) were determined onboard (see Raimbault et al., 2007). Pigment concentrations from noon profiles (local time) were determined using High Performance Liquid Chromatography (HPLC). For HPLC analyses, water samples were vacuum filtered through $25 \mathrm{~mm}$ diameter and $0.7 \mu \mathrm{m}$ porosity Whatman GF/F glass fibre filters (see Ras et al., 2007), where on average 97\% of Prochlorococcus cells are retained (Chavez et al., 1995). The above implies a maximum error of $3 \%$ on the total divinyl-chlorophyll $a$ concentrations (dv-chl $a$, pigment that is specific only to this group) determined using this technique. Daily integrated surface total irradiance was determined from on-board calibrated measurements.

All stations reported here were sampled at local noon time at 6 to 14 different depths from the surface down to $300 \mathrm{~m}$ (Fig. 1). The position of the deepest sampling depth was established relative to the position of the bottom of the photic layer, $\mathrm{Ze}(\mathrm{m})$ defined as the depth where the irradiance is reduced to $1 \%$ of its surface value. Five stations of very different trophic conditions, here referred to as long stations, 


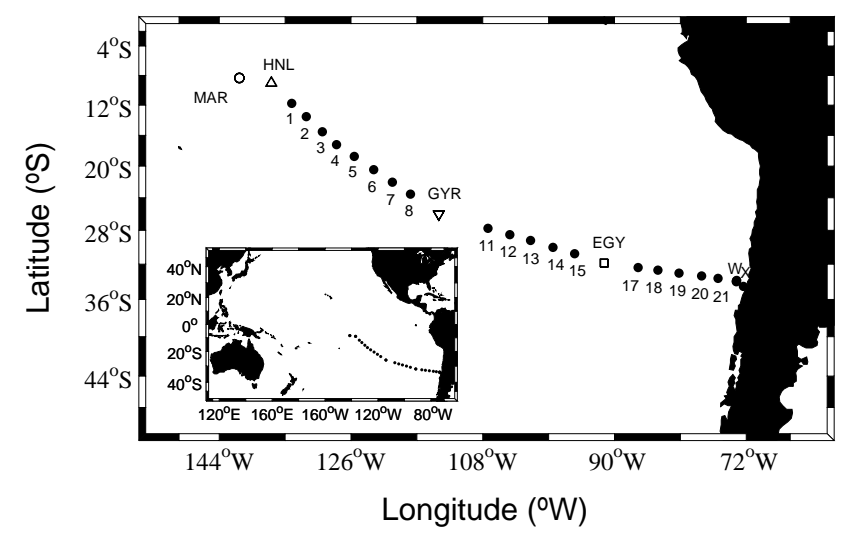

Fig. 1. BIOSOPE transect. In this study we include data from stations 1-8, 11-15 and 17-21, MAR, HNL, GYR, EGY, UPW (W) and $\operatorname{UPX}(\mathrm{X})$.

were also sampled at high frequency (i.e. every $3 \mathrm{~h}$ ) during 2 to 4 days: (1) mesotrophic (MAR, Marquesas Islands), (2) high nutrient-low chlorophyll (HNL, $\sim 9.0^{\circ} \mathrm{S}$ and $136.9^{\circ} \mathrm{W}$ ), (3) hyper-oligotrophic (GYR, $\sim 26.0^{\circ} \mathrm{S}$ and $\left.114.0^{\circ} \mathrm{W}\right)$, (4) oligotrophic (EGY, $\sim 31.8^{\circ} \mathrm{S}$ and $91.5^{\circ} \mathrm{W}$ ) and (5) eutrophic (UPW, highly productive upwelling region, $\sim 34.0^{\circ} \mathrm{S}$ and $73.3^{\circ} \mathrm{W}$ ) (Fig. 1). The coastal-most station (UPX) was additionally sampled to compare it with UPW's upwelling condition (Fig. 1).

Our results are presented in terms of oligo-, meso- and eutrophic conditions according to surface total chlorophyll $a$ concentrations (Tchla, chlorophyll $a+$ divinyl chlorophyll a) of $\leq 0.1,>0.1$ and $\leq 1$, and $>1 \mathrm{mg} \mathrm{m}^{-3}$, respectively (Antoine et al., 1996). This division has been used to characterize the trophic status of the ocean from space and we consider it as appropriate to describe the large spatial patterns investigated during the BIOSOPE cruise.

\subsection{Picoplankton analyses}

Prochlorococcus, Synechococcus and picophytoeukaryotes abundances were determined on fresh samples on board with a FACSCalibur (Becton Dickinson) flow cytometer. For bacterioplankton counts (Bacteria + Archaea), samples fixed either with paraformaldehyde at $1 \%$ or glutaraldehyde at $0.1 \%$ final concentration and quick-frozen in liquid nitrogen were stained with SYBR-Green I (Molecular Probes) and run in the same flow cytometer within two months after the end of the cruise. Reference beads (Fluoresbrite YG Microspheres, calibration grade $1.00 \mu \mathrm{m}$, Polysciences, Inc) were added to each sample before acquiring the data with the Cell Quest Pro software (Becton Dickinson) in logarithmic mode (256 channels). During data acquisition, between $5 \times 10^{3}$ and $300 \times 10^{3}$ events were registered in order to count at least 500 cells for each picoplanktonic group. The error associated with abundances determined using flow cytometry is $\leq 5 \%$ (D. Marie, unpublished data). The data

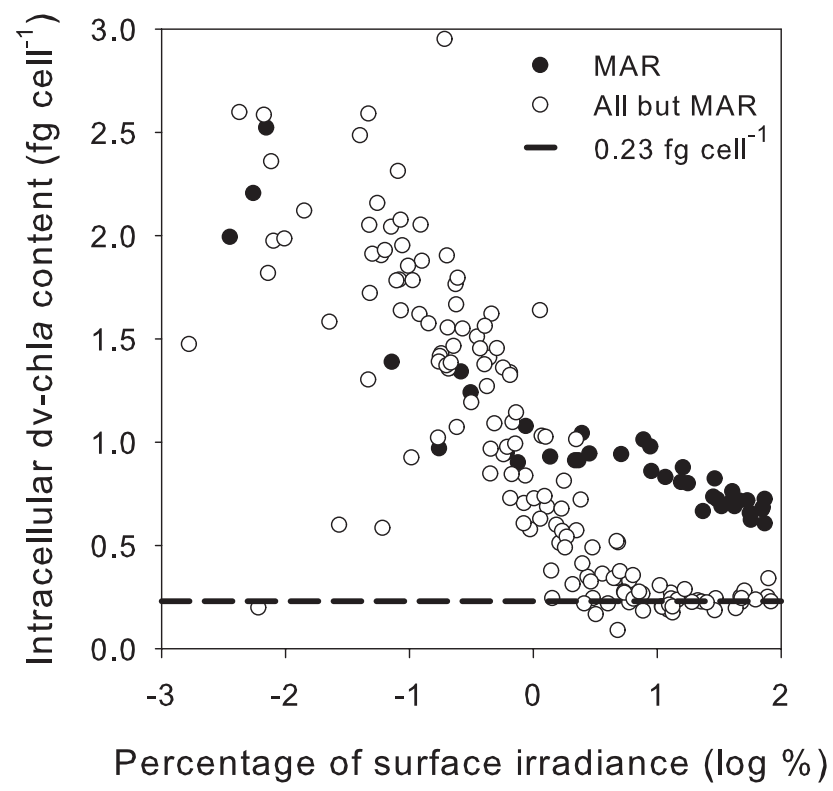

Fig. 2. Prochlorococcus intracellular dv-chla content (fg cell ${ }^{-1}$ ) as a function of the percentage of surface irradiance at MAR (filled circles) and the rest of the transect (empty circles). Dashed line indicates the average surface intracellular dv-chl $a$ content established at $0.23 \mathrm{fg} \mathrm{cell}^{-1}$.

were then analysed with the Cytowin software (Vaulot, 1989) to separate the picoplanktonic populations based on their scattering and fluorescence signals, according to Marie et al. (2000) (see Supp. Mat.: www.biogeosciences.net/4/837/ 2007/bg-4-837-2007-supplement.pdf).

Surface Prochlorococcus abundance for weakly fluorescent populations (i.e. $\sim 7 \%$ of total samples) was estimated by fitting a Gaussian curve to the data using Cytowin. When their fluorescence was too dim to fit the curve (e.g. surface and sub-surface samples at the center of the gyre) their abundance was estimated from dv-chl $a$ concentrations by assuming an intracellular pigment content of $0.23 \mathrm{fg} \mathrm{cell}^{-1}$ (see Supp. Mat.). This intracellular dv-chl $a$ content corresponds to the mean value obtained for cells in the surface layer (above $\sim 5 \%$ of surface light) by dividing the HPLCdetermined dv-chl $a$ by the cell number estimated from flow cytometry, considering all but the MAR data (Fig. 2). At the GYR station, Synechococcus and picophytoeukaryotes abundances above $100 \mathrm{~m}$ were only available for the first morning profile (samples taken above $90 \mathrm{~m}$ for the other GYR profiles are unfortunately not available). This profile showed that both groups' abundances were homogeneous over the first $100 \mathrm{~m}$, so we assumed the abundances measured at 90$100 \mathrm{~m}$ to be representative of the abundances within the 0 $100 \mathrm{~m}$ layer. All picoplankton abundances were then integrated from the surface to $1.5 \mathrm{Ze}$ rather than to $\mathrm{Ze}$, because deep chlorophyll maxima (DCM) were observed between these two depths at the center of the gyre. 

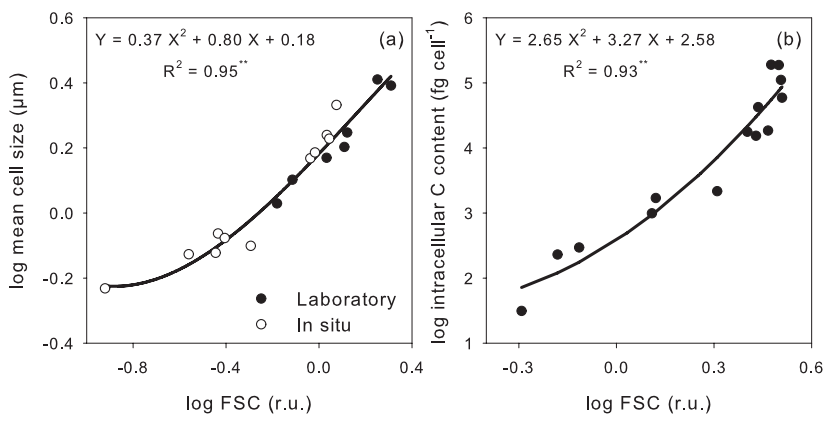

Fig. 3. Log-log relationships established between the flow cytometric forward scatter signal (FSC), expressed in units relative to reference beads (relative units, r.u.), and mean cell size in $\mu \mathrm{m}$ (a) and intracellular carbon (C) content in fig cell ${ }^{-1}$ (b). In (a), mean cell sizes measured on natural populations isolated in situ (empty circles) as well as on populations from culture (filled circles) are included. Mean intracellular carbon contents in (b) were obtained from culture cells. Carbon measurements were performed on triplicate with $\leq 5 \%$ of standard deviation. ${ }^{* *}$ indicates $p<0.0001$.

In order to establish a relationship between actual sizes (i.e. mean cell sizes actually measured) and the mean forward scatter cytometric signal normalized to the reference beads (FSC in relative units, r.u.; see Supp. Mat.: www.biogeosciences.net/4/837/2007/ bg-4-837-2007-supplement.pdf), in situ Prochlorococcus, Synechococcus and picophytoeukaryotes populations were sorted separately on board with a FACS Aria flow cytometer (Becton Dickinson). Each sorted population was then analysed with a Multisizer 3 Coulter Counter (Beckman Coulter) for size $(\mu \mathrm{m})$ and with the FACS Calibur flow cytometer for FSC. Several Synechococcus and picophytoeukaryotes populations isolated in situ could be measured with the Coulter Counter. Prochlorococcus size, on the other hand, could only be determined for one population because they were at the detection limit of the instrument. A similar analysis was performed on monospecific cultures of various picophytoplankton species (without pre-sorting) to combine both in situ and laboratory measurements to establish a log-log polynomial relationship between FSC and size (Fig. 3a). We believe that even though the left-most end of the fitted curve is driven by a sole data point, it is still very useful to the relationship because it represents the actual mean cell size of a natural Prochlorococcus population (i.e. $0.59 \mu \mathrm{m}$ ), corresponding to a mean FSC of 0.02 r.u. Based on this relationship established within the picophytoplankton size range, we calculated the upper size limit for the FSC settings we used during the whole cruise at $3 \mu \mathrm{m}$ (i.e. $\mathrm{FSC}=0.88$ r.u.).

Also using culture cells, we established a direct relationship between the mean cytometric FSC signal and intracellular carbon content to estimate Synechococcus and picophytoeukaryotes carbon biomass (Fig. 3b). To obtain intracellular carbon contents, a known volume of each cul- ture population was filtered onto GF/F filters previously precombusted at $400^{\circ} \mathrm{C}$, in triplicate. One blank filter per culture was put aside to be used as control. The number of phytoplankton and contaminating bacterioplankton cells retained in and passing through the filters were determined using flow cytometry (see Supp. Mat.: www.biogeosciences. net/4/837/2007/bg-4-837-2007-supplement.pdf). The filters were then dried at $60^{\circ} \mathrm{C}$ for $24 \mathrm{~h}$, fumigated with concentrated chlorhydric acid for 6 to $8 \mathrm{~h}$ to remove inorganic carbon and dried again for 6 to $8 \mathrm{~h}$. Each filter was finally put in a tin capsule and analysed with a CarbonHydrogen-Nitrogen (CHN) autoanalyzer (Thermo Finnigan, Flash EA 1112) (see Supp. Mat.: www.biogeosciences.net/4/ 837/2007/bg-4-837-2007-supplement.pdf). Carbon contents were estimated based on a calibration curve performed using Acetanilide.

Considering both size and carbon content derived from FSC, a conversion factor (in fgC $\mu \mathrm{m}^{-3}$ ) was established for Synechococcus and then applied to the mean cell size estimated for Prochlorococcus to obtain the intracellular carbon content of that group. Picophytoplankton carbon biomass was then calculated by multiplying cell abundance and intracellular carbon content for each group.

2.2 Beam attenuation coefficients specific for each picoplankton group

Profiles of the total particle beam attenuation coefficient at $660 \mathrm{~nm}\left(c_{\mathrm{p}}, \mathrm{m}^{-1}\right)$, a proxy for POC (e.g. Claustre et al., 1999), were obtained with a C-Star transmissometer (Wet Labs, Inc.) attached to the CTD rosette. Procedures for data treatment and validation have been described elsewhere (Loisel and Morel, 1998; Claustre et al., 1999). Inherent optical properties of sea water (IOP's), such as $c_{\mathrm{p}}$, depend exclusively on the medium and the different substances in it (Preisendorfer, 1961). The vegetal $\left(c_{\text {veg }}\right)$ and non-vegetal $\left(c_{\text {nveg }}\right)$ contribution (Eq. 1$)$ to the particle beam attenuation coefficient can therefore be expressed as

$c_{\mathrm{p}}=c_{\mathrm{veg}}+c_{\mathrm{nveg}}$

whereas the Prochlorococcus $\left(c_{\text {proc }}\right)$, Synechococcus $\left(c_{\text {syn }}\right)$, picophytoeukaryotes $\left(c_{\text {euk }}\right)$ and larger phytoplankton ( $>3 \mu \mathrm{m}, c_{\text {large }}$ ) contribution to the vegetal signal (Eq. 2) can be described by

$c_{\mathrm{veg}}=c_{\mathrm{proc}}+c_{\mathrm{syn}}+c_{\mathrm{euk}}+c_{\text {large }}$

Bacterioplankton $\left(c_{\text {bact }}\right)$, heterotrophs $\left(c_{\text {het }}\right)$ and detritus $\left(c_{\text {det }}\right.$ $=$ non living particles) contribute to the non-vegetal component (Eq. 3) as follows,

$$
\begin{aligned}
c_{\text {nveg }} & =c_{\mathrm{p}}-c_{\mathrm{veg}} \\
& =c_{\text {bact }}+c_{\text {het }}+c_{\text {det }} \\
& =c_{\text {bact }}+2 c_{\text {bact }}+c_{\text {det }} \\
& =3 c_{\text {bact }}+c_{\text {det }}
\end{aligned}
$$


where $c_{\text {het }}$ is assumed to be approximately $2 c_{\text {bact }}$ (Morel and Ahn, 1991). This assumption was adopted in order to be able to estimate the fraction of total particulate organic carbon corresponding to detritus, which is the group of particles contributing to $c_{\mathrm{p}}$ that is not directly measured, i.e. the unaccounted $c_{\mathrm{p}}$ (see below; Eq. 4).

Since particulate absorption is negligible at $660 \mathrm{~nm}$ (Loisel and Morel, 1998), beam attenuation and scattering are equivalent, so we can estimate $c_{\text {proc }}, c_{\text {syn }}, c_{\text {euk }}, c_{\text {large }}$ and $c_{\text {bact }}$ by determining the group-specific scattering coefficients $b_{i}$ $\left(\mathrm{m}^{-1}\right)=\mathrm{N}_{i}\left[s_{i} \mathrm{Q}_{b i}\right]$, where $i=$ proc, syn, euk, large or bact. We used flow cytometry to retrieve both picophytoplankton cell abundance $\left(\mathrm{N}_{i}\right.$, cells $\left.\mathrm{m}^{-3}\right)$ and mean cell sizes (through FSC, see Sect. 2.1). Mean geometrical cross sections $\left(s, \mathrm{~m}^{2}\right.$ cell $\left.^{-1}\right)$ were calculated from size, while $\mathrm{Q}_{b i}$ (660), the optical efficiency factors (dimensionless), were computed through the anomalous diffraction approximation (Van de Hulst, 1957) assuming a refractive index of 1.05 for all groups (Claustre et al., 1999). For Prochlorococcus and Synechococcus we used mean sizes obtained from a few samples, whereas for the picophytoeukaryotes we used the mean cell size estimated for each sample (see Supp. Mat.: www.biogeosciences.net/4/837/2007/ bg-4-837-2007-supplement.pdf). For samples where picophytoeukaryotes abundance was too low to determine their size we used the nearest sample value, i.e. the mean cell size estimated for the sample taken immediately above or below the missing one. This approximation was applied to $\sim 26 \%$ of the samples and although it may seem a large fraction, it corresponds mostly to deep samples where cell abundance was very low. Low cell abundances will result in low biomasses and it is therefore unlikely that the error associated with this approximation will introduce important errors in the carbon biomass estimates. For bacterioplankton we used a value of $0.5 \mu \mathrm{m}$, as used by Claustre et al. (1999). Finally, once $c_{\mathrm{veg}}$, $c_{\text {bact }}$ and therefore $c_{\text {het }}$ are determined, $c_{\text {det }}$ is obtained directly by difference (Eq. 4 ).

$$
\begin{aligned}
c_{\text {det }} & =c_{\text {nveg }}-c_{\text {bact }}-c_{\text {het }} \\
& =c_{\text {nveg }}-c_{\text {bact }}-2 c_{\text {bact }} \\
& =c_{\text {nveg }}-3 c_{\text {bact }}
\end{aligned}
$$

Contributions to $c_{\mathrm{p}}$ by larger phytoplanktonic cells in the western and eastern part of the transect were estimated by assuming that peaks larger than $3 \mu \mathrm{m}$ in the particle size distribution data obtained either with the Coulter Counter or with a HIAC optical counter (Royco; Pacific Scientific) corresponded to autotrophic organisms (see Supp. Mat.: www.biogeosciences.net/4/837/ 2007/bg-4-837-2007-supplement.pdf). Coulter Counter data were only available for 1 (surface samples, $\leq 5 \mathrm{~m}$ ) to 3 different depths. Thus, in order to obtain water column profiles for MAR, HNL, EGY and UPW, the estimated $c_{\text {large }}$ were extrapolated by assuming $c_{\text {large }}=0$ at the depth where no peak $>3 \mu \mathrm{m}$ was detected (usually below $50 \mathrm{~m}$ ). When only surface data were available, $c_{\text {large }}$ was assumed to be negligible at the depth where chlorophyll fluorescence became lower than the surface one. Group-specific attenuation signals were integrated from the surface down to $1.5 \mathrm{Ze}$ (wa-

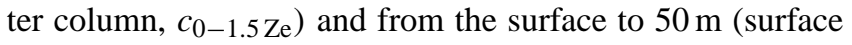
layer, $c_{0-50 \mathrm{~m}}$ ) to estimate their contribution to integrated $c_{\mathrm{p}}$.

Finally, $c_{\mathrm{p}}(660)$ was converted to particulate organic carbon (POC) by using the empirical relationship established by Claustre et al. (1999) for the tropical Pacific (Eq. 5), which has proven to be valid as part of BIOSOPE (see Stramski et al., 2007).

POC $\left(\mathrm{mg} \mathrm{m}^{-3}\right)=c_{\mathrm{p}}\left(\mathrm{m}^{-1}\right) \times 500\left(\mathrm{mg} \mathrm{m}^{-2}\right)$

Through the above relationship $c_{\mathrm{p}}$ explains $\sim 92 \%$ of the variance in POC concentration (Claustre et al., 1999). To evaluate the ability of Tchla and $c_{\mathrm{p}}$ to trace spatial changes in picophytoplankton biomass along the transect, we used local noon time data within the integration depth $(0$ to $1.5 \mathrm{Ze})$ from the stations where no large phytoplankton cells were detected with the particle counters (Coulter or HIAC), i.e. stations 3 to $15+$ GYR. We chose these stations because we do not have intracellular carbon content data for larger cells to include in the photosynthetic carbon biomass estimates.

\section{Results}

The sampled transect included South Pacific Tropical Waters (SPTW), with a clear salinity maximum extending from the surface down to $150 \mathrm{~m}$ between HNL and GYR, Eastern South Pacific Central Waters (ESPCW) characterized by salinities of 34.5 to 36 (Fig. 4a) and temperatures of 15 to $20^{\circ} \mathrm{C}$ at the centre of the gyre (GYR to EGY) and colder and fresher waters at the Chilean coast (Claustre et al., 2007). Limits between oligo-, meso- and eutrophic conditions were set at 133,89 and $74.5^{\circ} \mathrm{W}$ according to the measured surface chlorophyll $a$ concentrations, as explained above. Under oligotrophic conditions nitrate concentrations were close to $0 \mu \mathrm{M}$ or undetectable between the surface and $150-200 \mathrm{~m}$, and still very low $(\sim 2.5 \mu \mathrm{M})$ between the latter depth and $1.5 \mathrm{Ze}$ (Fig. 4b). Expectedly, nutrient concentrations were higher under mesotrophic conditions and highest near the coast (see Raimbault et al., 2007), whereas phosphate was never a limiting factor (Moutin et al., 2007).

The hyper-oligotrophic centre of the South Pacific Subtropical Gyre (SPSG), i.e. the clearest waters of the world's ocean (Morel et al., 2007), was characterized by extremely low surface Tchla concentrations $\left(<0.03 \mathrm{mg} \mathrm{m}^{-3}\right.$; see Ras et al., 2007) and undetectable nutrient levels (see Raimbault et al., 2007), greatly differing from the Marquesas Islands' mesotrophic conditions and the typical High Nutrient - Low Chlorophyll situation (i.e. HNL) encountered at the borders of the gyre, and the upwelling conditions observed at the coast. 

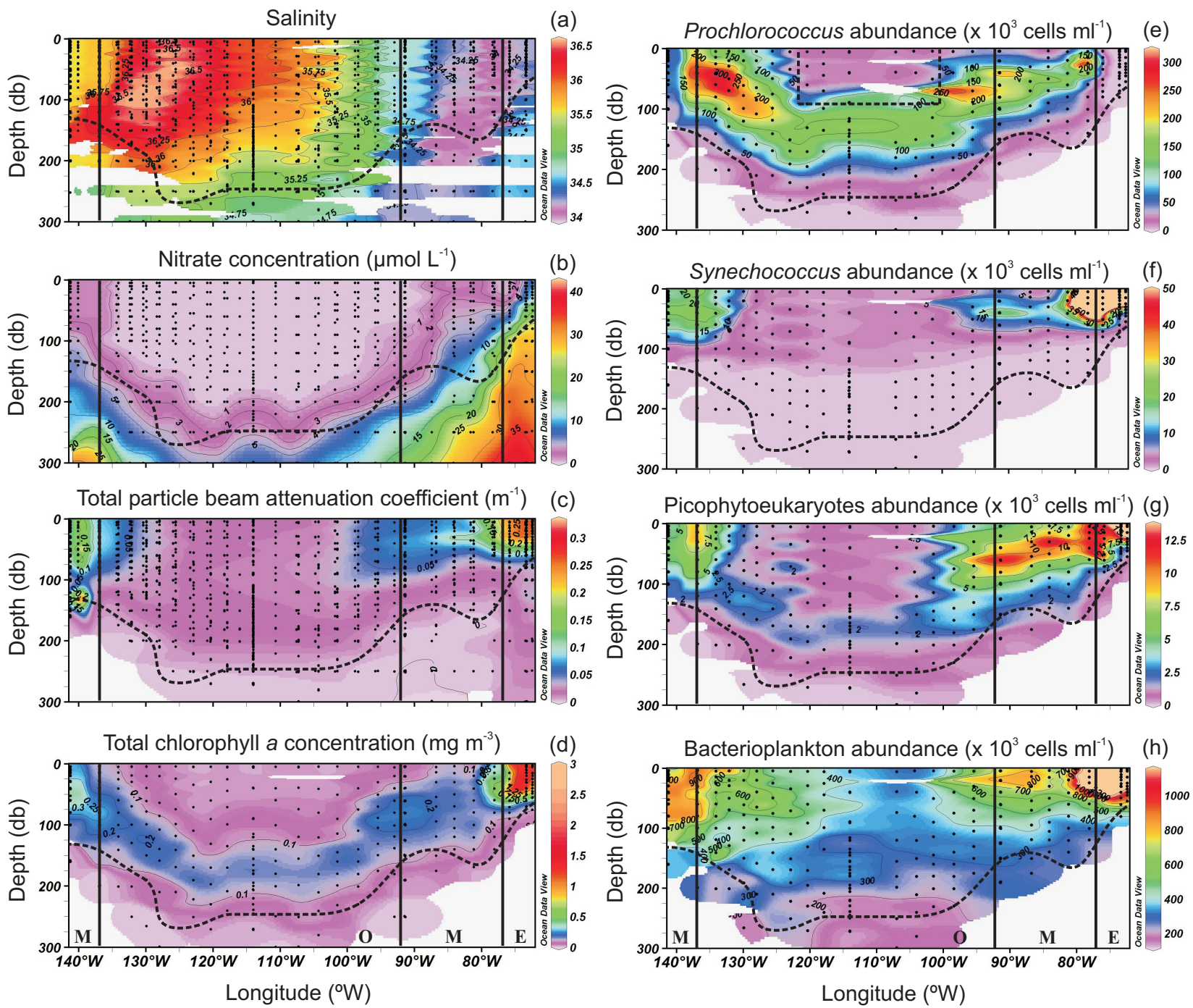

Fig. 4. Salinity (a), nitrate concentration in $\mu \mathrm{mol} \mathrm{L}^{-1}$ (b), total particle beam attenuation coefficient in $\mathrm{m}^{-1}$ (c), total chlorophyll $a$ concentration in $\mathrm{mg} \mathrm{m}^{-3}$ (d) Prochlorococcus $(\mathbf{e})$, Synechococcus $(\mathbf{f})$, picophytoeukaryotes $(\mathbf{g})$ and bacterioplankton $(\mathbf{h})$ abundances $\left(\times 10^{3}\right.$ cells $\mathrm{ml}^{-1}$ ). Vertical black lines indicate from left to right the limits between meso- (M), oligo- (O), meso- (M) and eutrophic (E) conditions. Horizontal black dashed line corresponds to the depth of the $1.5 \mathrm{Ze}$. Black dashed square in (e) indicates where Prochlorococcus abundances were estimated from $\mathrm{dv}$-chl $a$ concentration.

\subsection{Picoplankton numerical abundance}

All groups' abundances tended to decrease towards the centre of the gyre. Prochlorococcus was highest at the western (up to $300 \times 10^{3}$ cells $\mathrm{ml}^{-1}$ around $50 \mathrm{~m}$, associated with SPTW) and eastern (up to $200 \times 10^{3}$ cells $\mathrm{ml}^{-1}$ in the 50 to $100 \mathrm{~m}$ layer) borders of the oligotrophic region (Fig. 4e). Peaks in Synechococcus (up to $190 \times 10^{3}$ cells $\mathrm{ml}^{-1}$; Fig. 4f), picophytoeukaryotes $\left(10-70 \times 10^{3}\right.$ cells $\mathrm{ml}^{-1}$; Fig. $\left.4 \mathrm{~g}\right)$ and bacterioplankton abundances (up to $2 \times 10^{6}$ cells ml $^{-1}$; Fig. $4 \mathrm{~h}$ ) were registered near the coast. Deep Prochlorococcus $\left(100-150 \times 10^{3}\right.$ cells $\mathrm{ml}^{-1}$ between 50 and $200 \mathrm{~m}$; Fig. $\left.4 \mathrm{e}\right)$ and picophytoeukaryotes $\left(\sim 2 \times 10^{3}\right.$ cells $\mathrm{ml}^{-1}$ between 150 and $200 \mathrm{~m}$; Fig. 4g) maxima were recorded at the centre of the gyre following the pattern of Tchla concentrations ( $\sim 0.15 \mathrm{mg} \mathrm{m}^{-3}$; Fig. $4 \mathrm{~d}$ ), above the deep chlorophyll maximum (DCM) for the former and within the DCM depth range for the latter (Figs. 4e and g). Synechococcus reached lower depth ranges than the rest of the groups everywhere along the transect (Fig. 4f). In terms of chlorophyll biomass, the importance of the DCM at the centre of the gyre is highlighted when comparing the surface-to-DCM average ratios for the different long stations: $0.67 \pm 0.13$ at MAR, $0.44 \pm 0.04$ at HNL, $0.12 \pm 0.02$ at GYR and $0.27 \pm 0.02$ at EGY.

Water column integrated picoplankton abundance ( 0 to $1.5 \mathrm{Ze}$ ) was strongly dominated by bacterioplankton along 

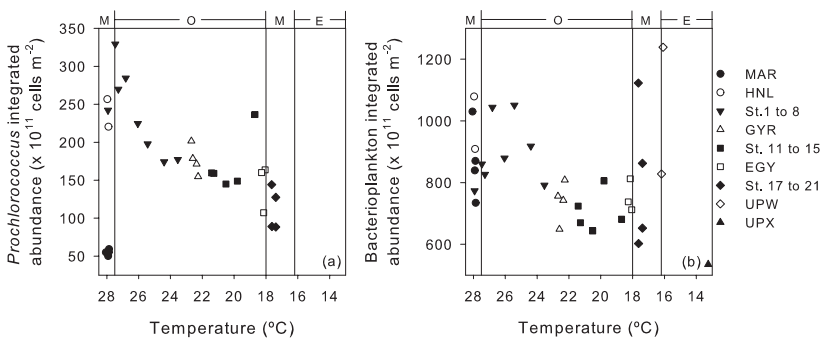

Fig. 5. Prochlorococcus (a), and bacterioplankton (b) integrated abundances ( 0 to $1.5 \mathrm{Ze}, \times 10^{11}$ cells $\mathrm{m}^{-2}$ ) as a function of surface temperature, which was representative of the general eastward decrease in water temperature within the integration depth (0 to $1.5 \mathrm{Ze}$ ) along the transect. Vertical lines indicate the limits established between meso- $(\mathrm{M})$, oligo- $(\mathrm{O})$ and eutrophic $(\mathrm{E})$ conditions.

Table 1. Correlation matrix for log integrated (0 to $1.5 \mathrm{Ze})$ picoplankton abundances $($ Proc $=$ Prochlorococcus, Syn $=$ Synechococcus, Euk = picophytoeukaryotes and Bact $=$ bacterioplankton; $\times 10^{11}$ cells $\mathrm{m}^{-2}$ ) and $\log$ integrated total chlorophyll $a$ $\left(\mathrm{Tchl} a ; \mathrm{mg} \mathrm{m}^{-2}\right.$ ), considering the entire transect. Picophytoplankton $=$ Proc + Syn + Euk; picoplankton $=$ Proc + Syn + Euk + Bact.

\begin{tabular}{cccccc}
\hline & Proc & Syn & Euk & Bact & Tchla \\
\hline Proc & 1.00 & n.s & n.s & n.s & $-0.42^{*}$ \\
Syn & - & 1.00 & $0.68^{* *}$ & n.s & $0.82^{* *}$ \\
Euk & - & - & 1.00 & n.s & n.s \\
Bact & - & - & - & 1.00 & $0.46^{*}$ \\
Picophytoplankton & - & - & - & - & $0.58^{*}$ \\
Picoplankton & - & - & - & - & $0.61^{* *}$ \\
\hline
\end{tabular}

Upper right values show correlation coefficients with their corresponding level of significance:

** significance level $<0.0001 ;{ }^{*}$ significance level $<0.05$; n.s., not statistically significant

the whole transect $(83 \pm 7 \%$ of total picoplanktonic cells), followed by Prochlorococcus when present (up to $27 \%$ under oligotrophic conditions), the contributions by Synechococcus ( 0.1 to $3.7 \%$ ) and picophytoeukaryotes $(0.2$ to $3.1 \%$ ) being almost negligible. When not considering MAR, Prochlorococcus showed an evident positive relationship with surface temperature (Fig. 5a), which was representative of the general eastward decrease in water temperature within the integration depth (0 to $1.5 \mathrm{Ze})$ along the transect (see Claustre et al., 2007). Picophytoeukaryotes and Synechococcus abundances did not follow the surface temperature trend. Bacterioplankton, on the other hand, followed the Prochlorococcus pattern under oligotrophic conditions (Fig. 5b).

When considering the entire data set, Prochlorococcus integrated abundance was negatively correlated to Tchla, whereas bacterioplankton and Synechococcus (strongest correlation) were both positively correlated to this variable (Table 1). Bacterioplankton abundance covaried with phyto-
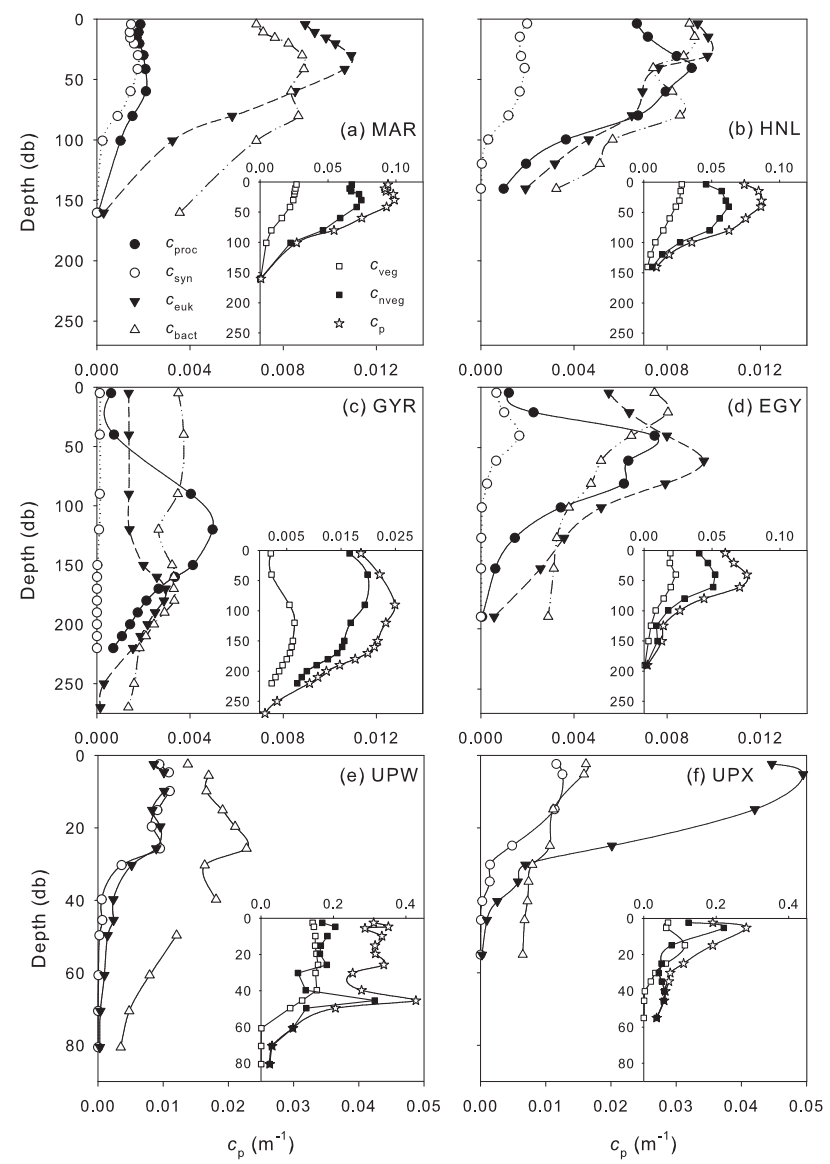

Fig. 6. Mean group-specific particle beam attenuation coefficients for Prochlorococcus $\left(c_{\text {proc }}\right)$, Synechococcus $\left(c_{\mathrm{syn}}\right)$, picophytoeukaryotes $\left(c_{\text {euk }}\right)$, bacterioplankton $\left(c_{\text {bact }}\right)$. Insets contain the vegetal $\left(c_{\mathrm{veg}}\right)$, non-vegetal $\left(c_{\text {nveg }}\right)$, and total particle beam attenuation coefficient $\left(c_{\mathrm{p}}\right)$ in $\mathrm{m}^{-1}$. For MAR (a), HNL (b), GYR (c), EGY (d), UPW (e) and UPX (f). Note that UPW and UPX scales are equal to each other and different from the rest. For MAR, HNL, GYR and EGY all scale are the same except for GYR's $c_{\mathrm{p}}, c_{\mathrm{veg}}$ and $c_{\text {nveg. }}$

plankton biomass (Table 1). Except for Synechococcus and picophytoeukaryotes, no statistically significant correlations were observed between picoplanktonic groups (Table 1).

\subsection{Picoplankton contributions to $c_{\mathrm{p}}$, a proxy for POC}

Mean pico- and large phytoplankton cell sizes used to estimate the group-specific attenuation cross sections are summarized in Table 2 and compared with values from the literature. These values and the standard errors associated with them (Table 2) were obtained using the relationship established between mean FSC and cell size (Fig. 3a). The largest size difference between previous studies and the present one was observed for the picophytoeukaryotes (Table 2). For this group, the attenuation coefficients 
Table 2. Picoplankton mean cell size $(\mu \mathrm{m})$, volume $\left(\mu \mathrm{m}^{3}\right)$ and intracellular carbon content $\left(\mathrm{fgC}\right.$ cell $\left.{ }^{-1}\right)$.

\begin{tabular}{|c|c|c|c|c|}
\hline Group & Mean cell size $(\mu \mathrm{m})$ & Mean cell volume $\left(\mu \mathrm{m}^{3}\right)$ & $\begin{array}{l}\text { Intracellular carbon } \\
\text { content }(\text { fgC cell }\end{array}$ & Reference \\
\hline \multirow[t]{4}{*}{ Prochlorococcus } & $0.68 \pm 0.08$ & 0.17 & $29 \pm 11^{* * *}$ & 1 \\
\hline & 0.74 & 0.21 & - & 2 \\
\hline & 0.7 & 0.18 & - & 3 \\
\hline & $0.63 \pm 0.2$ & 0.13 & 29 & 4 \\
\hline \multirow[t]{4}{*}{ Synechococcus } & $0.86 \pm 0.1^{*}$ and $1.16 \pm 0.02^{* *}$ & 0.33 and 0.82 & $60 \pm 19^{*}$ and $140 \pm 9^{* *}$ & 1 \\
\hline & 0.90 & 0.38 & & 2 \\
\hline & 1.2 & 0.90 & & 3 \\
\hline & $0.95 \pm 0.31$ & 0.45 & 100 & 4 \\
\hline \multirow[t]{4}{*}{ Picophytoeukaryotes } & $1.74 \pm 0.13($ range $=1.37$ to 1.99$)$ & 2.76 & $730 \pm 226($ range $=257$ to 1266$)$ & 1 \\
\hline & 1.26 & 1.05 & - & 2 \\
\hline & 2.28 & 6.21 & - & 3 \\
\hline & 2.35 & 6.8 & 1500 & 4 \\
\hline \multirow[t]{3}{*}{ Large phytoplankton } & 3.3 (MAR) to $\sim 20$ (UPW) & 18.8 to 4189 & - & 1 \\
\hline & 10 to 22 & 523.6 to 5575.28 & - & 2 \\
\hline & 6 to 13 & 113.1 to 1150.35 & - & 5 \\
\hline \multirow[t]{5}{*}{ Bacterioplankton } & 0.5 & 0.07 & - & 1,3 \\
\hline & 0.56 & 0.09 & - & 2 \\
\hline & $0.46 \pm 0.14$ & 0.05 & - & 4 \\
\hline & 0.50 to 0.65 & 0.07 to 0.13 & - & 6 \\
\hline & 0.15 to 0.73 & 0.002 to 2 & - & 7 \\
\hline
\end{tabular}

1 This study

2 Chung et al. (1998); Equatorial Pacific

3 Claustre et al. (1999); Tropical Pacific Ocean

${ }^{4}$ Zubkov et al. (2000); North and South Atlantic Subtropical Gyres

5 Oubelkheir et al. (2005); Mediterranean Sea

${ }^{6}$ Ulloa et al. (1992); Western North Atlantic

7 Gundersen et al. (2002); Bermuda Atlantic Time Series (BATS)

* For most of the transect and ${ }^{* *}$ for UPX, the most coastal station

*** Obtained using the conversion factor $171 \pm 15 \mathrm{fg} \mathrm{C} \mu \mathrm{m}^{3}$ derived from Synechococcus (see Sect. 2.1)

were determined by changes in both size (decreasing towards the coast; see Supp. Mat.: www.biogeosciences. net/4/837/2007/bg-4-837-2007-supplement.pdf) and abundance, when considering a constant refractive index. As a result, for instance, an average decrease in mean cells size of $0.22 \mu \mathrm{m}\left(0.0056 \mu \mathrm{m}^{3}\right)$ from MAR to $\mathrm{HNL}$ (see Supp. Mat.: www.biogeosciences.net/4/837/2007/ bg-4-837-2007-supplement.pdf) counteracts the higher cell abundance in the latter (Fig. 6g; Table 2) to modulate $c_{\text {euk }}$ along the transect (Figs. 6 and 7). In the case of Prochlorococcus, the mean value presented in Table 2 was obtained from samples taken at different depths along the entire transect, except at the centre of the gyre where the FSC signal could only be retrieved at depth. Larger cell sizes for this group were always found in deeper samples (not shown).

Along the transect, the shape and magnitude of the vertical $c_{\mathrm{p}}$ profiles were mainly determined by the non-vegetal compartment, with $c_{\mathrm{p}}$ and $c_{\text {nveg }}$ presenting the same vertical pattern at all long stations (Fig. 6). At MAR and HNL, $c_{\mathrm{p}}$ was rather homogeneous in the top $50 \mathrm{~m}$ and declined be- low this depth, whereas $c_{\text {nveg }}$ decreased systematically with depth (Figs. 6a and b). At GYR $c_{\mathrm{p}}$ and $c_{\text {nveg }}$ subsurface maxima were both observed around $100 \mathrm{~m}$, these two variables being highest around $40 \mathrm{~m}$ at EGY (Figs. 6c and d). Both $c_{\mathrm{p}}$ and $c_{\mathrm{veg}}$ tended to be lower under hyper- and oligotrophic conditions at the centre of the gyre and were highest at UPW (Fig. 6). Both Prochlorococcus (when present) and picophytoeukaryotes usually presented subsurface maxima in their attenuation coefficients (e.g. at GYR around $125 \mathrm{~m}$ for the former and between 150 and $250 \mathrm{~m}$ for the latter; Fig. 6c) except at UPW, where $c_{\text {euk }}$ tended to decrease below $30 \mathrm{~m}$ (Fig. 6e). UPX profiles were included to highlight the differences observed with UPW, the other upwelling station (Figs. 6e and f). No large phytoplankton peaks (>3 $\mu \mathrm{m})$ were detected between Station 3 and 15, including GYR.

Total and group-specific integrated attenuation coefficients ( 0 to $1.5 \mathrm{Ze}$ ) tended all to decrease from the western side towards the center of the gyre and increased again towards the coast (Fig. 7a). The integrated nonvegetal attenuation coefficient (detritus + bacterioplankton 

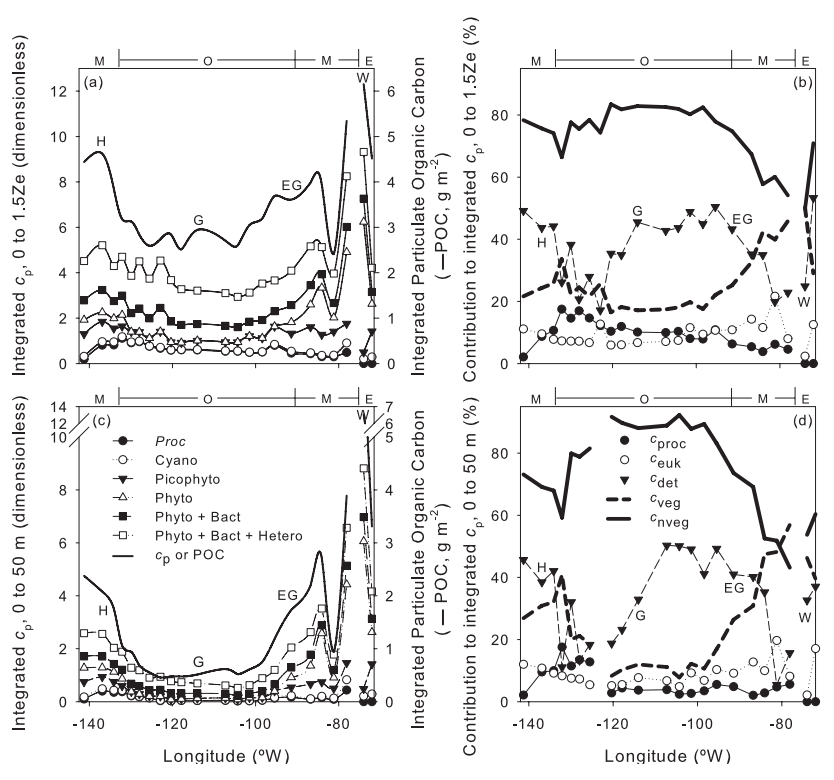

Fig. 7. Integrated attenuation coefficients for Prochlorococcus (Proc), Proc + Synechococcus (Cyano), Cyano + picophytoeukaryotes (Picophyto), Picophyto + nanophytoplankton (Phyto), Phyto + bacterioplankton (Phyto + Bact), Phyto + Bact + heterotrophic protists (Phyto + Bact + Hetero) and Phyto + Bact + Hetero + detritus $\left(c_{\mathrm{p}}\right)$ in the 0 to $1.5 \mathrm{Ze}$ layer (a) and the 0 to $50 \mathrm{~m}$ layer (c). The contributions by Prochlorococcus ( $\left.c_{\text {proc }}\right)$, picophytoeukaryotes $\left(c_{\text {euk }}\right)$, detritus $\left(c_{\text {det }}\right)$, vegetal $\left(c_{\mathrm{veg}}\right)$ and non-vegetal $\left(c_{\text {nveg }}\right)$ particles to the corresponding total integrated attenuation coefficients are shown in (b) and (d). The top black lines in (a) and (c) correspond to the total integrated particle beam attenuation coefficient $\left(c_{\mathrm{p}}\right.$, left hand axis) and particulate organic carbon concentration (POC, right hand axis) estimated from $c_{\mathrm{p}}$ using Claustre et al. (1999) relationship (see Sect. 2.2; Eq. 5). M, O and E stand for meso-, oligo- and eutrophic conditions (top of each panel). H, G, EG and W indicate HNL, GYR, EGY and UPW stations.

+ heterotrophic organisms) was quite variable, constituting $\geq 70 \%$ of $c_{0-1.5 \mathrm{Ze}}$ in most of the transect, reaching the highest $(83 \%)$ and lowest (50\%) contributions at GYR and UPW, respectively (Fig. 7b). Detritus being estimated by difference (Eq. 4$), c_{\text {det }}$ and $c_{\text {veg }}$ 's contributions to $c_{0-1.5 \mathrm{Ze}}$ followed a general opposite trend, presenting similar values near the meso-oligotrophic limits $\left(\sim 128\right.$ and $\left.87^{\circ} \mathrm{W}\right)$ (Fig. 7b). Detritus contribution to $c_{0-1.5 \mathrm{Ze}}$ was always $\leq 50 \%$, the lowest values being associated with highest vegetal contributions (Fig. 7b). Interestingly, between the two extreme trophic conditions encountered at GYR (hyper-oligotrophic; see Claustre et al., 2007) and UPW (eutrophic), $c_{0-1.5 \mathrm{Ze}}$ and integrated $c_{\mathrm{veg}}$ increased $\sim 2$ - and 6-fold, respectively, whereas integrated $c_{\text {nveg }}$ and $c_{\text {det }}$ were only $\sim 1.2-$ and $1.1-$ fold higher at the upwelling station (Fig. 7a). Furthermore, in terms of contribution to $c_{0-1.5 \mathrm{Ze}}, c_{\mathrm{veg}}$ was $\sim 3$ times higher at UPW, $c_{\text {nveg }}$ and $c_{\text {det }}$ representing only about half of the percentage estimated at GYR (Fig. 7b).

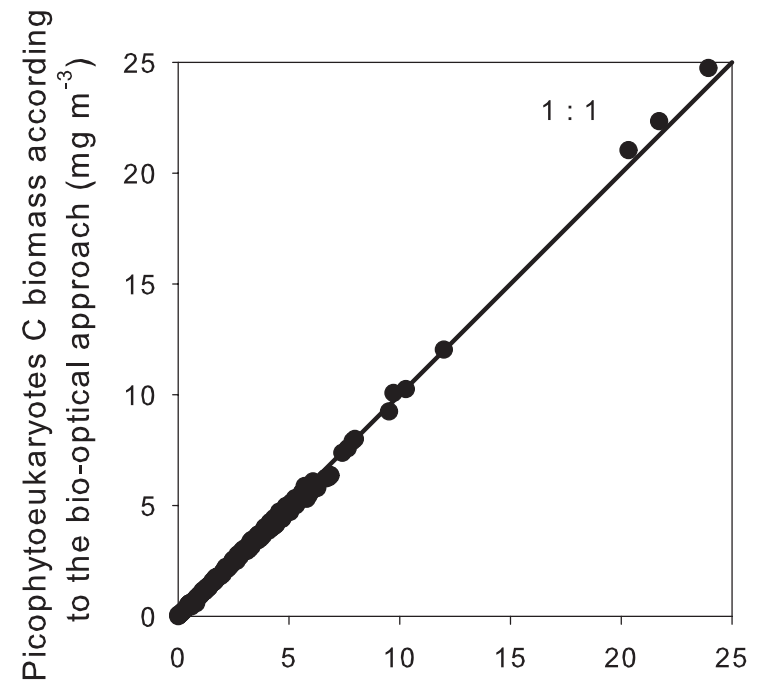

Picophytoeukaryotes $\mathrm{C}$ biomass according to the intracellular $\mathrm{C}$ content approach $\left(\mathrm{mg} \mathrm{m}^{-3}\right)$

Fig. 8. Picophytoeukaryotes carbon biomass estimated from intracellular carbon content (see Sect. 2.1) compared to that estimated by calculating $c_{\text {euk }}$ contribution to $c_{\mathrm{p}}$, the latter assumed to be equivalent to POC (see Sect. 2.2). Note that both approaches gave very similar results. 1:1 indicates the 1-to-1 line relating both estimates.

Mean integrated Prochlorococcus (when present) and picophytoeukaryotes contributions to $c_{0-1.5 \mathrm{Ze}}$ for the whole transect were equivalent $(9.7 \pm 4.1$ and $9.4 \pm 3.8 \%$, respectively), although the latter were clearly more important under mesotrophic conditions in both absolute values (Fig. 7a) and relative terms (Fig. 7b). Synechococcus attenuation coefficients were too low (Fig. 7a) to contribute significantly to $c_{\mathrm{p}}$ (only $1.0 \pm 1.0 \%$ on average), so we did not include them in Fig. 7b. Bacterioplankton attenuation coefficients varied little along the transect and were always lower than all phytoplankton combined (Fig. 7b). Large phytoplankton attenuation coefficients were lower than that of the picophytoplankton (cyanobacteria and picophytoeukaryotes combined) in the western part of the transect and higher or similar near the coast (Fig. 7a), their contributions to $c_{\mathrm{p}}$ following the same trend (included in $c_{\text {veg }}$ 's contribution, Fig. $7 \mathrm{~b}$ ).

When comparing $c_{0-1.5 \mathrm{Ze}}$ to $c_{0-50 \mathrm{~m}}$ and their integrated group-specific attenuation coefficients, it becomes clear that not considering data below $50 \mathrm{~m}$ leads to very different results in most of the transect and especially at the centre of the gyre (Figs. 7a and c). For instance, whereas at UPW $c_{0-1.5 \mathrm{Ze}}$ and $c_{0-50 \mathrm{~m}}$ were equivalent, the former is 2 - and the latter 13-fold higher than the corresponding GYR integrated values (Figs. 7a and c). Similarly, there was a 2-fold difference in $c_{\mathrm{veg}}$ 's contributions to $c_{0-1.5 \mathrm{Ze}}$ and $c_{0-50 \mathrm{~m}}$ at the centre of the gyre (Figs. $7 b$ and $d$ ). 

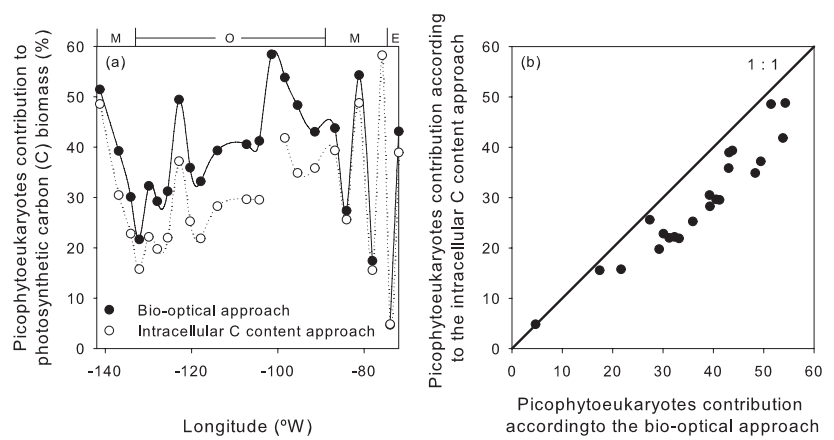

Fig. 9. Picophytoeukaryotes contribution to the photosynthetic carbon biomass as derived from $c_{\text {euk }}$ 's contribution to $c_{\mathrm{veg}}$ by applying Eq. (5) (bio-optical method) and as obtained using intracellular carbon contents in Table 2 to estimate picophytoplankton carbon biomass (a). When comparing the results obtained using both approaches, it can clearly be seen that the contributions estimated using the intracellular carbon (C) content approach are lower than those estimated using the bio-optical approach, with almost all data points being below the 1-to-1 line relating both estimates (b).

3.3 Phytoplanktonic carbon biomass stocks and spatial variability

To avoid the use of carbon conversion factors from the literature, in the present work we used two different approaches to estimate the picophyoteukaryotes carbon biomass: (1) from intracellular carbon content (Fig. 3b; see Sect. 2.1) and (2) calculating $c_{\text {euk }}$ contribution to $c_{\mathrm{p}}$, the latter assumed to be equivalent to POC (see Sect. 2.2). Both approaches gave very similar results (Fig. 8), indicating that the premise that all picophytoeukaryotic organisms have the same refractive index $(\sim 1.05)$ is valid for the sampled transect, even if we know that this group is usually constituted by diverse taxa (Moonvan der Staay et al., 2001). The above provides strong support for the use of optical techniques and theory to determine picophytoeukaryotes carbon biomass, under the sole condition of using actual mean cell sizes.

The deconvolution of $c_{\mathrm{p}}$ indicates that at the centre of the gyre $\left(\sim 120.36\right.$ to $98.39^{\circ} \mathrm{W}$ or Station 7 to $\left.14+\mathrm{GYR}\right)$ the photosynthetic biomass, which was dominated by picophytoplankton, constituted $\sim 18 \%$ of the total integrated $c_{\mathrm{p}}$ or POC (Fig. 7b). Even more interestingly, when looking at the vegetal compartment alone, $\sim 43 \%$ of this photosynthetic biomass would correspond to the picophytoeukaryotes (Fig. 9a; filled circles). Let us now assume that the contribution to integrated $c_{\mathrm{p}}$ by all phytoplanktonic groups is representative of their contribution to POC, as proven for the picophytoeukaryotes (see above). Under this assumption, picophytoeukaryotes would constitute $51 \%$ of the total phytoplankton carbon biomass (large phytoplankton included) at MAR, about $39 \%$ at HNL and GYR and $43 \%$ at EGY (Fig. 9a; filled circles). At UPW, however, where mean integrated POC estimated from $c_{\mathrm{p}}$ (see Sect. 2.2) was $\sim 6 \mathrm{~g} \mathrm{~m}^{-2}$ (right axis on
Fig. 7a), picophytoeukaryotes would only constitute $5 \%$ of the photosynthetic biomass (Fig. 9a; filled circles). When considering the whole transect, picophytoeukaryotes mean contribution to the total photosynthetic carbon biomass (i.e. $c_{\text {euk }}$ 's mean contribution to $c_{\mathrm{p}}$ ) was $\sim 38 \%$.

Intracellular carbon contents used to estimate picophytoplankton biomass through the relationship established with FSC (Fig. 3b) are given in Table 2. Contributions to POC by Prochlorococcus and Synechococcus were $\sim 1.7$ and 1.5 times higher when estimated using this approach rather than attenuation coefficients (not shown). Using these higher values for cyanobacteria and assuming that the contribution by large phytoplankton is equivalent to $c_{\text {large }}$ 's contribution to $c_{\mathrm{p}}$, picophytoeukaryotes mean contribution to the total photosynthetic carbon biomass along the transect would be $\sim 30 \%$, representing $\sim 28$ instead of $43 \%$ at the centre of the gyre (Fig. 9a; empty circles). These contributions are slightly lower than the ones estimated through the optically-based approach, with almost all data points being below the 1-to-1 line relating both estimates (Fig. 9b).

Regarding spatial variability, both Tchl $a \quad(\mathrm{r}=0.67$, $p<0.001)$ and $c_{\mathrm{p}}(\mathrm{r}=0.53, p<0.001)$ were correlated to the dominant picophytoplankton carbon biomass, i.e. Prochlorococcus + picophytoeukaryotes, between Stations 3 and 15, GYR included (Fig. 10). The results of a t-test on the z-transformed correlation coefficients (Zokal and Rohlf, 1994) indicates that both correlations are not significantly different $(p>0.05)$. Therefore, Tchl $a$ and $c_{\mathrm{p}}$ were equally well correlated to the picophytoplanktonic biomass. Synechococcus biomass, on the other hand, was negatively correlated to Tchla (Fig. 10a) and positively to $c_{\mathrm{p}}$ (Fig. 10b). However, despite the differences observed between this cyanobacterium and the other two groups, correlation coefficients calculated for total picophytoplankton biomass (i.e. dominant + Synechococcus; not shown) were not significantly different $(p>0.05)$ from those calculated for the dominant groups (Fig. 10). Synechococcus had no influence on the general relationships because of its negligible biomass. Tchl $a$ and $c_{\mathrm{p}}$ were therefore useful in tracing total picophytoplanktonic carbon biomass in the part of the transect where no large phytoplankton was detected (i.e. Stations 3 to $15+G Y R$ ).

\section{Discussion and conclusion}

\subsection{Picoplankton abundance}

Macroecological studies indicate that $66 \%$ of the variance in picophytoplankton abundance can be explained by temperature (the dominant factor), nitrate and chlorophyll $a$ concentration $(\mathrm{Li}, 2007)$. It has also been established that higher Prochlorococcus abundances are observed in more stratified waters, whereas Synechococcus and picophytoeukaryotes are more abundant when mixing prevails (e.g. Blanchot and 
Rodier, 1996; Shalapyonok et al., 2001). Across the eastern South Pacific Ocean temperature, especially for Prochlorococcus and bacterioplankton (Fig. 5), and nitrate concentration along the transect (see Fig. 4b) appear important in modulating picophytoplankton abundance, their influence varying according to the prevailing trophic conditions.

As expected (e.g. Gasol and Duarte, 2000), integrated bacterioplankton abundances covaried with phytoplankton biomass (Table 1). Integrated picophytoeukaryotes abundance was the only one to vary independently from Tchla when considering the whole transect (Table 1), suggesting that the factors controlling picophytoplankton population, such as sinking, sensitivity to radiation, grazing, viral infection, etc. (Raven, 2005) acted differently on this group. Thus, the ecology of picophytoeukaryotes needs to be studied in further detail. Across the eastern South Pacific, surface bacterioplankton concentrations were similar to those found by Grob et al. (2007) at $32.5^{\circ} \mathrm{S}$. However, in the deep layer of the hyper-oligotrophic part of the gyre $(200 \mathrm{~m})$ this group was 2.5 times more abundant than published by Grob et al. (2007). Given the correlation between integrated bacterioplankton abundance and Tchl $a$ concentration (Table 1), the latter could be attributed to the presence of deep Prochlorococcus and picophytoeukaryotes maxima that were not observed by Grob et al. (2007). Such deep maxima are a recurrent feature in the oligotrophic open ocean (Figs. 4e and g; Table 3). Along the transect, picophytoplankton abundances were usually within the ranges established in the literature for oligo-, meso- and eutrophic regions of the world's ocean (see Table 3). It is worth noticing that our estimates for surface Prochlorococcus abundance were, to our knowledge, the lowest ever estimated for the open ocean (see Table 3), although a possible underestimation cannot be ruled out.

The presence of the mentioned groups under extreme poor conditions suggests a high level of adaptation to an environment where inorganic nutrients are below detection limit. Although little is known on picophytoeukaryotes metabolism, several cyanobacteria ecotypes have been shown to grow on urea and ammonium (Moore et al., 2002). Ammonium uptake at the centre of the gyre was low but still detectable (Raimbault et al., 2007). Considering that heterotrophic bacteria would be responsible for $\sim 40 \%$ of this uptake in marine environments (Kirchman, 2000), the possibility of surface picophytoplankton growing on this form of nitrogen at the centre of the gyre cannot be discarded.

\subsection{Picoplankton contribution to $c_{\mathrm{p}}$}

The larger increase of integrated $c_{\mathrm{veg}}$ as compared to $c_{\mathrm{nveg}}$ observed between extreme trophic conditions (see Sect. 3.2) indicates that across the eastern South Pacific spatial variability in the vegetal compartment was more important than the non-vegetal one in shaping the water column optical properties, at least the particle beam attenuation coefficient. As expected (e.g. Chung et al., 1996; Loisel and Morel, 1998;
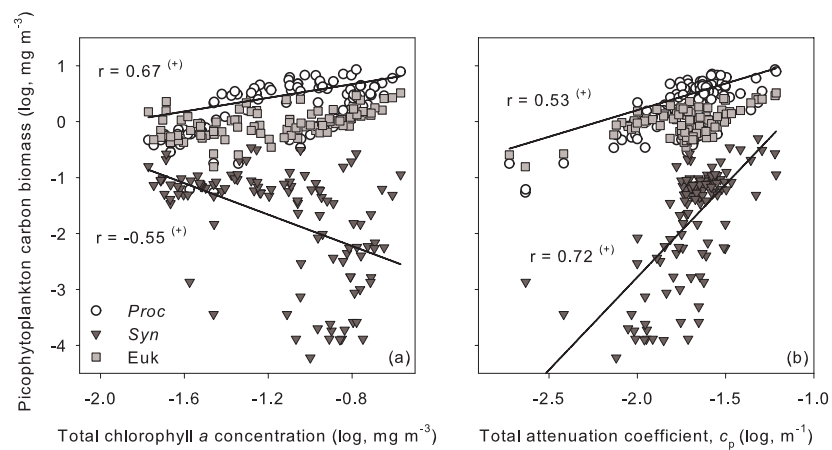

Fig. 10. Log-log relationships for Prochlorococcus (Proc), Synechococcus (Syn) and picophytoeukarytos (Euk) carbon biomass $\left(\mathrm{mg} \mathrm{m}^{-3}\right)$ with total chlorophyll $a$ concentration in $\mathrm{mg} \mathrm{m}^{-3}$ (a) and total particle beam attenuation coefficient in $\mathrm{m}^{-1}(\mathbf{b})$. Only data from Stations 3 to 15 and GYR, where no large phytoplankton cells were detected, and between the surface and $1.5 \mathrm{Ze}$ are included (see Sect. 2.2). Correlation coefficients (r) were calculated for the sum of Proc and Euk (upper values) and for Syn carbon biomass (lower values) with Tchl $a(\mathrm{a})$ and $c_{\mathrm{p}}(\mathrm{b}) .{ }^{(+)}$indicates $p<0.001$.

Claustre et al., 1999), $c_{\mathrm{p}}$ and $c_{\mathrm{veg}}$ tended to be lower under hyper- and oligotrophic conditions at the centre of the gyre and were highest at UPW. Here, the highest $c_{\mathrm{p}}$ and $c_{\mathrm{veg}}$ were associated with mature upwelling conditions characterized by the highest primary production (Moutin et al., 2007) and Tchla (Fig. 4d), and low nutrient concentration (Fig. 4b; Raimbault et al., 2007).

Although the non-vegetal particles tended to dominate the $c_{\mathrm{p}}$ signal, and therefore POC, regardless of trophic condition (Fig. 7b; e.g. Chung et al., 1998; Claustre et al., 1999; Oubelkheir et al., 2005), this dominance seems to weaken from oligo- to eutrophic conditions (Claustre et al., 1999; this study). Here we showed that under mature upwelling conditions (UPW) the contribution by vegetal and non-vegetal particles may even be equivalent (Fig. 7b), in contrast with the invariant $\sim 80 \% c_{\text {nveg }}$ contribution estimated by Oubelkheir et al. (2005) for different trophic conditions. We therefore emphasize the importance of using complementary data to interpret bio-optical measurements since, for instance, the $\sim 2.3$-fold difference in $c_{\text {veg }}$ 's contribution to $c_{\mathrm{p}}$ observed between our UPW results and those published by Ouberkheir et al. (2005) seems to be related to the state of development of the upwelling event (mature versus early).

At the hyper-oligotrophic centre of the gyre, $c_{\text {euk }}$ contribution to $c_{0-1.5 \mathrm{Ze}}$ was equivalent to the one possibly overestimated (because of the larger cell size assumed) by Claustre et al. (1999). The above highlights the importance of making good size estimates when decomposing the total attenuation signal since, for example, a difference of $1.02 \mu \mathrm{m}$ in size leads to a 10 -fold difference in the scattering cross-section calculated for picophytoeukaryotes (Claustre et al., 1999; Oubelkheir et al., 2005). In the present 
Table 3. Prochlorococcus, Synechococcus and picophytoeukaryotes abundances $\left(\times 10^{3}\right.$ cells $\left.\mathrm{ml}^{-1}\right)$ registered during spring time in different regions of the world's ocean under varying trophic conditons.

\begin{tabular}{|c|c|c|c|c|}
\hline Trophic condition & Prochlorococcus & Synechococcus & Picophytoeukaryotes & Reference \\
\hline \multirow[t]{2}{*}{ Hyper-oligotrophic } & $16-18^{*}$ & $1.2-1.6^{*}$ & $0.76-1.3^{*}$ & \multirow[t]{2}{*}{1 (GYR) } \\
\hline & $150-160(125 \mathrm{~m})$ & $0.8-1.4(125 \mathrm{~m})$ & $1.8-2.3(175 \mathrm{~m})$ & \\
\hline \multirow[t]{11}{*}{ Oligotrophic } & $35-40^{*}$ & $6.9-8.6^{*}$ & $4.5-4.9^{*}$ & \multirow[t]{2}{*}{1 (EGY) } \\
\hline & $200-250(50-75 \mathrm{~m})$ & $20(50 \mathrm{~m})$ & $14(60 \mathrm{~m})$ & \\
\hline & $240(0$ to $100 \mathrm{~m})$ & $1.5(0$ to $100 \mathrm{~m})$ & $0.8-1(0$ to $100 \mathrm{~m})$ & 2 \\
\hline & $30^{*}$ & $0.7^{*}$ & $0.5^{*}$ & \multirow[t]{2}{*}{3} \\
\hline & $200(120 \mathrm{~m})$ & $1-1.5(50-125 \mathrm{~m})$ & $2(140-150 \mathrm{~m})$ & \\
\hline & $100-150^{*}$ & $3-30^{*}$ & $0.6-2^{*}$ & \multirow[t]{2}{*}{4} \\
\hline & $100(120 \mathrm{~m})$ & $1(120-160 \mathrm{~m})$ & $1-2(80-120 \mathrm{~m})$ & \\
\hline & $115^{*}$ & $0.2-1(0$ to $100 \mathrm{~m})$ & $0.25-0.5^{*}$ & \multirow[t]{2}{*}{5} \\
\hline & $150-200(50-100 \mathrm{~m})$ & & Up to $3(100 \mathrm{~m})$ & \\
\hline & $60(0$ to $100 \mathrm{~m})$ & $2.5(0$ to $50-100 \mathrm{~m})$ & $2-4^{*}$ & 6 \\
\hline & & & $2(100 \mathrm{~m})$ & \\
\hline \multirow[t]{6}{*}{ HNL } & 200 (surf) & $10-28$ (surf) & \multirow[t]{2}{*}{$5-9(0$ to $80 \mathrm{~m})$} & \multirow[t]{2}{*}{1} \\
\hline & $270(30-60 \mathrm{~m})$ & $25(50 \mathrm{~m})$ & & \\
\hline & $150-300(0$ to $80 \mathrm{~m})$ & $3-5(0$ to $80 \mathrm{~m})$ & $0.6-1(0$ to $100 \mathrm{~m})$ & 3 \\
\hline & $200(0$ to $50 \mathrm{~m})$ & $8(0$ to $100 \mathrm{~m})$ & $3(0$ to $100 \mathrm{~m})$ & 7 \\
\hline & $100(80 \mathrm{~m})$ & & & \\
\hline & $200(30$ and $60 \mathrm{~m})$ & 15 and $13(30$ and $60 \mathrm{~m})$ & 6 and $5(30$ and $60 \mathrm{~m})$ & 8 \\
\hline \multirow[t]{3}{*}{ Mesotrophic } & $50-60(0$ to $80 \mathrm{~m})$ & $17-20(0$ to $60 \mathrm{~m})$ & $3-5(0$ to $80 \mathrm{~m})$ & 1 (MAR) \\
\hline & $30-200^{*}$ & $5-44^{*}$ & $3-18^{*}$ & \multirow[t]{2}{*}{6} \\
\hline & $1-40(100 \mathrm{~m})$ & $0.2-3(100 \mathrm{~m})$ & $0.4-4(100 \mathrm{~m})$ & \\
\hline \multirow[t]{3}{*}{ Eutrophic } & - & $60-200$ & $5-10$ & 1 (UPW) \\
\hline & - & $50-250$ & $10-60$ & 9 \\
\hline & - & Up to 150 & Up to $80-90$ & 10 \\
\hline
\end{tabular}

* Surface data

1 This study

2 Campbell and Vaulot (1993); Subtropical North Pacific (ALOHA)

3 Vaulot et al. (1999); Subtropical Pacific $\left(16^{\circ} \mathrm{S} ; 150^{\circ} \mathrm{W}\right)$. These authors considered their surface Prochlorococcus abundances as "severely underestimated".

${ }^{4}$ Zubkov et al. (2000); North and South Atlantic Subtropical Gyres

5 Veldhuis and Kraay (2004); Eastern North Atlantic Subtropical Gyre

${ }^{6}$ Grob et al. (2007); Eastern South Pacific

${ }^{7}$ Mackey et al. (2002); Equatorial Pacific

${ }^{8}$ Landry et al. (2003); Equatorial Pacific

${ }^{9}$ Worden et al. (2004); Southern California Bight, North Pacific

${ }^{10}$ Sherr et al. (2005); Oregon upwelling ecosystem, North Pacific

work, picophytoplankton populations were isolated on board by flow-cytometry cell sorting in order to measure their actual sizes using a particle counter (see Sect. 2.1). It is the first time to our knowledge that such direct measurements have been made in the field. For future studies we recommend to measure the different picophytoplankton mean cell sizes in situ for at least a few samples, including surface and deep populations in order to consider possible vertical variability. If these samples are taken under different oceanographic conditions, we also recommend including samples from each one of these conditions.
By establishing a relationship with FSC to estimate actual picophytoplankton cell size (Fig. 3a), we confirmed that picophytoeukaryotes were more important contributors to $c_{\mathrm{p}}$ than cyanobacteria under both meso- and eutrophic conditions (Claustre et al., 1999). The uncertainties in this relationship are larger for cyanobacteria (lower part of the curve; Fig. 3a) than for picophytoeukaryotes. However, Prochlorococcus and Synechococcus' mean cell sizes measured in situ were $\leq 0.59$ (only one isolated population could be measured with the Coulter Counter, the rest being too small) and $\leq 0.87 \mu \mathrm{m}$, respectively (see 
Table A, Supp. Mat.: www.biogeosciences.net/4/837/2007/ bg-4-837-2007-supplement.pdf). We therefore believe that these group's mean cell sizes, and therefore their contributions to $c_{\mathrm{p}}$ along the transect, may have been at most overrather than underestimated by this relationship. Differences in cell size (Table 2) would also explain the much lower Synechococcus contribution to $c_{\mathrm{p}}$ observed in the hyperoligotrophic centre of the gyre compared to that published by Claustre et al. (1999) for the tropical Pacific $\left(16^{\circ} \mathrm{S}, 150^{\circ} \mathrm{W}\right)$.

Only data collected at local noon time were used to estimate group-specific attenuation coefficients, to avoid errors associated with the natural diel variability that has been observed in the refractive index of picophytoplankton cells from culture (e.g. Stramski et al., 1995; DuRand and Olson, 1998; DuRand et al., 2002). Here we showed that the premise that all picophytoeukaryotes are homogeneous spheres with the same refractive index of 1.05 (assumptions of the anomalous diffraction approximation) is valid for the sampled transect when actual mean cell sizes are used. In the case of Synechococcus, a high refractive index of 1.083 (Aas, 1996) would only increase this group's mean attenuation cross-section by an almost negligible 6\%. Given their low abundance compared to the other groups, the resulting increase in their contribution to $c_{\mathrm{p}}$ would be even lower.

If Prochlorococcus were to have a refractive index of 1.06 for instance, their mean attenuation cross-section would be $43 \%$ higher than the one calculated here. Nevertheless, the resulting Prochlorococcus' contribution to $c_{\mathrm{p}}$ for the entire transect would only be $4 \pm 2 \%$ higher. However, this group's contribution to $c_{\text {veg }}$ would increase by $18 \pm 2 \%$ on average, constituting up to $99 \%$ of the vegetal compartment under hyper-oligotrophic conditions. Such high contribution contradicts both HPLC (dv-chl $a$ to Tchl $a$ ratios of $\sim 0.2$ to 0.5 ; see Ras et al., 2007) and flow cytometry data (see Synechococcus and picophytoeukaryotes abundances; Figs. $4 \mathrm{f}$ and $\mathrm{g}$ ) and appears hence not possible. We therefore believe that the assumption of a refractive index of 1.05 for cyanobacteria is appropriate for the purposes of the present work. It is worth noticing that lower refractive indexes for these two groups would only reduce their contribution to $c_{\mathrm{p}}$ (and therefore POC) and $c_{\mathrm{veg}}$, the contribution by picophytoeukaryotes resulting even more important than stated in this work.

Regarding mean cell size, deep Prochlorococcus cells are larger than surface ones (e.g. Li et al., 1993; this study). The former are better represented than the latter in the data set used to estimate mean Prochlorococcus cell size for the transect, since surface FSC signals could not be retrieved for a large area at the centre of the gyre. We therefore consider that the mean cell size used here for this group could be at most overestimated, i.e. biased towards a larger value due to the fewer surface data available. Hence, picophytoeukaryotes' contributions to $c_{\text {veg }}$ could only be underestimated. The above highlights the importance of this group in terms of photosynthetic biomass in the open ocean.
Definitively the largest uncertainties in the deconvolution of $c_{\mathrm{p}}$ are related to the determination $c_{\text {bact }}$ and $c_{\text {het }}$, which have a direct influence on $c_{\text {det }}$ 's estimates (see Sect. 2.2, Eq. 4). First, bacterioplankton cells were assumed to have a mean cell size of $0.5 \mu \mathrm{m}$. Taking the minimum and maximum sizes presented in Table 2 (i.e. 0.46 and $0.73 \mu \mathrm{m}$ ), the scattering cross section for bacterioplankton would be $\sim 28 \%$ lower and 4.5 times higher than the one used here, respectively. The lower scattering cross sections for these two groups would imply an underestimation of detritus' contribution to $c_{\mathrm{p}}$ of only $11 \pm 3 \%$ on average for the entire transect. A scattering cross section 4.5 times higher (i.e. $0.73 \mu \mathrm{m}$ of mean cell size) would imply contributions $\geq 100 \%$ to $c_{\mathrm{p}}$, and therefore POC, by bacteria and heterotrophic protests alone, which seems unrealistic. Using a mean cell size of $0.6 \mu \mathrm{m}$, i.e. the average value between 0.46 and $0.73 \mu \mathrm{m}$, leads to the same kind of overestimation of the heterotrophic contributions to $c_{\mathrm{p}}$. Based on the above, we consider the assumption of a $0.5 \mu \mathrm{m}$ mean cell size for bacterioplankton to be appropriate for our estimates, since at most it would slightly underestimate detritus.

Following Claustre et al. (1999), here we assumed that $c_{\text {het }}=2 c_{\text {bact }}$ (see Sect. 2.2, Eq. 3). The range reported by Morel and Ahn (1993) for this conversion factor is 1.8 to 2.4. Using these values instead of 2 would result in an average increase and decrease in $c_{\text {det }}$ 's contribution to $c_{\mathrm{p}}$ across the eastern South Pacific of $2 \pm 1 \%$ and $4 \pm 2 \%$, respectively, which in both cases is negligible. It is worth noticing that even if larger errors were associated with the assumptions made in this work regarding bacterioplankton and heterotrophic protists, our results and conclusions regarding picophytoeukaryotes contributions to $c_{\mathrm{p}}$, and therefore POC, and to the photosynthetic carbon biomass across the eastern South Pacific would not change.

\subsection{Phytoplankton carbon biomass stocks and spatial vari- ability}

One of the most important observations of the present study is that spatial variability in the open-ocean, where no large phytoplankton was detected, picophytoplankton carbon biomass can be traced by changes in both Tchl $a$ and $c_{\mathrm{p}}$ (Fig. 10). While chlorophyll concentration has widely been used as a proxy for photosynthetic carbon biomass, the use of $c_{\mathrm{p}}$ is more controversial. For instance, although $c_{\mathrm{p}}$ seems to be a better estimate of phytoplankton biomass than Tchla in Case I waters (Behrenfeld and Boss, 2003) and within the mixed layer of the eastern Equatorial Pacific (Behrenfeld and Boss, 2006), chlorophyll concentration would work better in subtropical stratified waters (Huot et al., 2007). Our results indicate that Tchl $a$ and $c_{\mathrm{p}}$ would be equally useful estimates of photosynthetic carbon biomass in the South Pacific gyre, where it is mainly constituted by picophytoplankton $(\leq 3 \mu \mathrm{m})$. However, it is important to highlight that in order to estimate the photosynthetic carbon biomass from $c_{\mathrm{p}}$ it is 
necessary to have information or make some assumptions on the contributions by vegetal and non-vegetal particles to this coefficient. In this case, picophytoplankton biomass and $c_{\mathrm{p}}$ were positively correlated such as that the former could be retrieved from the latter. Despite of the stated limitations, the bio-optical approach used in the present work could be a good alternative for large scale open ocean surveys, especially considering that $c_{\mathrm{p}}$ measurements are much less timeconsuming than determining chlorophyll concentration and can also be obtained at a much higher vertical resolution. Further research should be done to test the ability of $c_{\mathrm{p}}$ in tracing phytoplankton biomass in the ocean.

Although when present Prochlorococcus largely dominates in terms of abundance, the picophytoeukaryotes would constitute $\sim 38 \%$ on average of the total integrated phytoplankton carbon biomass (Prochlorococcus + Synechococcus + picophytoeukaryotes + large phytoplankton) estimated from $c_{\text {euk }}$ 's contribution to $c_{\text {veg }}$ (Fig. 9a, filled circles; see Sect. 3.3). Furthermore, under oligotrophic conditions this group constituted $\sim 43 \%$ of the photosynthetic carbon biomass. Previous studies indicate that picophytoeukaryotes largely dominate the vegetal compartment in the equatorial Pacific (DuRand et al., 1996; Claustre et al., 1999) and the picophytoplanktonic carbon biomass across the eastern South Pacific along $32.5^{\circ} \mathrm{S}$ (Grob et al., 2007). Here we showed that this group constitutes a very important and in some cases a dominant fraction of $c_{\text {veg }}$ across the eastern South Pacific, confirming the findings by Grob et al. (2007). The above also agrees with what has been observed in the North and South Atlantic Subtropical Gyres (Zubkov et al., 2000). Picophytoeukaryotes also dominated the picophytoplanktonic carbon biomass in the coastal region, as previously indicated by Worden et al. (2004) and Grob et al. (2007).

Picophytoeukaryotes contributions obtained by estimating cyanobacteria biomass from intracellular carbon content were probably underestimated compared to those obtained using the bio-optical approach (Fig. 9b) because of the conversion factor used for Prochlorococcus (Table 2). We believe that establishing a relationship between intracellular carbon content and FSC for this cyanobacterium, as we did for Synechococcus and picophytoeukaryotes, would lead to contributions similar to those estimated using attenuation coefficients. It is worth noticing that higher or lower cyanobacteria carbon biomasses would only modify the y-intercept of the biomass relationships with Tchl $a$ and $c_{\mathrm{p}}$ (Fig. 10), but not their slope or their strength.

When normalized to $1 \mu \mathrm{m}^{3}$, maximal growth rates estimated for picophytoeukaryotes are higher than for Prochlorococcus (Raven, 2005, and references therein). Considering that the former are $\sim 16$ times larger than the latter in terms of mean cell volume, the amount of carbon passing through the picophytoeukaryotes could be very important. For the same reason, this group could also be the most important contributor to export fluxes in the open ocean, since picophytoplankton share of this carbon pathway seems to be much more important than previously thought (Richardson and Jackson, 2007; Barber, 2007). The role of this group in carbon and energy flow would therefore be crucial.

Picophytoeukaryotes carbon biomass in the open ocean seems to be much more important than previously thought. Across the eastern South Pacific, this group's biomass is almost equivalent to that of Prochlorococcus under hyperoligotrophic conditions and even more important under mesotrophic ones. The role of picophytoeukaryotes in biogeochemical cycles needs to be evaluated in the near future. Further attention needs to be focused on this group.

Acknowledgements. This work was supported by the Chilean National Commission for Scientific and Technological Research (CONICYT) through the FONDAP Program and a graduate fellowship to C. Grob; the ECOS (Evaluation and Orientation of the Scientific Cooperation, France)-CONICYT Program, the French program PROOF (Processus Biogeochimiques dans l'Océan et Flux), Centre National de la Recherche Scientifique (CNRS), the Institut des Sciences de l'Univers (INSU), the Centre National d'Etudes Spatiales (CNES), the European Space Agency (ESA), the National Aeronautics and Space Administration (NASA) and the Natural Sciences and Engineering Research Council of Canada (NSERC). This is a contribution of the BIOSOPE project of the LEFE-CYBER program. D. Tailliez and C. Bournot are warmly thanked for their efficient help in CTD rosette management and data processing. We also thank the scientific party and the Captain and crew of the RV L'Atalante during the BIOSOPE Expedition; F. Thièche for her help with laboratory work; L. Farías and M. Gallegos for organic carbon analyses, B. Gentili for PAR data processing and R. Wiff for help with statistical analyses.

Edited by: E. Boss

\section{References}

Aas, E.: Refractive index of phytoplankton derived from its metabolite composition, J. Plankton Res., 18, 2223-2249, 1996.

Antoine, D., André, J. M., and Morel, A.: Oceanic primary production II. Estimation at global scale from satellite (Coastal Zone Color Scanner) chlorophyll, Global Biogeochem. Cycles, 10, 57-69, 1996.

Barber, R. T.: Picoplankton Do Some Heavy Lifting, Science, 315, 777-778, 2007.

Behrenfeld, M. J. and Boss, E.: The beam attenuation to chlorophyll ratio: an optical index of phytoplankton physiology in the surface ocean?, Deep Sea Res. Part I, 50, 1537-1549, 2003.

Behrenfeld, M. J. and Boss, E.: Beam attenuation and chlorophyll concentration as alternative optical indices of phytoplankton biomass, J. Mar. Res., 64, 431-451, 2006.

Bissett, W. P., Walsh, J. J., Dieterle, D. A., and Carder, K. L.: Carbon cycling in the upper waters of the Sargasso Sea: I. Numerical simulation of differential carbon and nitrogen fluxes, Deep Sea Res. I, 46, 205-269, 1999.

Blanchot, J. and Rodier, M.: Picophytoplankton abundance and biomass in the western Tropical Pacific Ocean during the 1992 
El Nino year: Results from flow cytometry, Deep-Sea Res., 43, 877-896, 1996.

Campbell, L. and Vaulot, D.: Photosynthetic picoplankton community structure in the subtropical North Pacific Ocean near Hawaii (station ALOHA), Deep Sea Res. I, 40, 2043-2060, 1993.

Carr, M.-E., Friedrichs, M. A. M., Schmeltz, M., Aita, M. N., Antoine, D., Arrigo, K. R., Asanuma, I., Aumont, O., Barber, R., Behrenfeld, M., Bidigare, R., Buitenhuis, E. T., Campbell, J., Ciotti, A., Dierssen, H., Dowell, M., Dunne, J., Esaias, W., Gentili, B., Gregg, W., Groom, S., Hoepffner, N., Ishizaka, J., Kameda, T., Quéré, C. L., Lohrenz, S., Marra, J., Mélin, F., Moore, K., Morel, A., Reddy, T. E., Ryan, J., Scardi, M., Smyth, T., Turpie, K., Tilstone, G., Waters, K., and Yamanaka, Y.: A comparison of global estimates of marine primary production from ocean color, Deep Sea Res. II, 53, 741-770, 2006.

Chavez, F. P., Buck, K. R., Bidigare, R. R., Karl, D. M., Hebel, D., Latasa, M., and Campbell, L.: On the chlorophyll a retention properties of glass-fiber GF/F filters, Limnol. Oceanogr., 40, 428-433, 1995.

Chen, C.-T. A., Liu, K.-K., and MacDonald, R. W.: Continental margin exchanges. Ocean Biogeochemistry, in: The Role of the Ocean Carbon Cycle in Global Change, edited by: Fasham, M. J. R., IGBP Book Series, Springer, 53-97, 2003.

Chisholm, S. W., Olson, R. J., Zettler, E. R., Goericke, R., Waterbury, J. B., and Welschmeyer, N. A.: A novel free-living prochlorophyte occurs at high cell concentrations in the oceanic euphotic zone, Nature, 334, 340-343, 1988.

Chung, S. P., Gardner, W. D., Richardson, M. J., Walsh, I. D., and Landry, M. R.: Beam attenuation and microorganisms: spatial and temporal variations in small particles along $14 \mathrm{O}^{\prime \prime} \mathrm{W}$ during the 1992 JGOFS EqPac transects, Deep Sea Res. II, 43, 12051226, 1996.

Chung, S. P., Gardner, W. D., Landry, M. R., Richardson, M. J., and Walsh, I. D.: Beam attenuation by microorganisms and detrital particles in the Equatorial Pacific, J. Geophys. Res., 103(C6), 12 669-12 681, 1998.

Claustre, H., Morel, A., Babin, M., Cailliau, C., Marie, D., Marty, J. C., Tailliez, D., and Vaulot, D.: Variability in particle attenuation and chlorophyll fluorescence in the Tropical Pacific: Scales, patterns, and biogeochemical implications, J. Geophys. Res., 104(C2), 3401-3422, 1999.

Claustre, H., Huot, Y., Obernosterer, I., Gentili, B., Tailliez, D., and Lewis, M.: Gross community production and metabolic balance in the South Pacific Gyre, using a non intrusive bio-optical method, Biogeosciences Discuss., 4, 3089-3121, 2007, http://www.biogeosciences-discuss.net/4/3089/2007/.

DuRand, M. D. and Olson, R. J.: Contributions of phytoplankton light scattering and cell concentration changes to diel variations in beam attenuation in the equatorial Pacific from flow cytometric measurements of pico-, ultra- and nanoplankton, Deep Sea Res. Part II, 43, 891-906, 1996.

DuRand, M. D. and Olson, R. J.: Diel patterns in optical properties of the chlorophyte Nannochloris sp.: Relating individual-cell to bulk measurements, Limnol. Oceanogr., 43, 1107-1118, 1998.

DuRand, M. D., Green, R. E., Sosik, H. M., and Olson, R. J.: Diel variations in optical properties of Micromonas pusilla (Prasinophyceae), J. Phycol., 38, 1132-1142, 2002.

Falkowski, P. G., Barber, R. T., and Smetacek, V.: Biogeochemical Controls and Feedbacks on Ocean Primary Production, Science,
200-206, 1998.

Field, C. B., Behrenfeld, M. J., Randerson, J. T., and Falkowski, P.: Primary Production of the Biosphere: Integrating Terrestrial and Oceanic Components, Science, 281, 237-240, 1998.

Gardner, W. D., Mishonov, A. V., and Richardson, M. J.: Global POC concentrations from in-situ and satellite data, Deep Sea Res. II, 53, 718-740, 2006.

Gasol, J. M. and Duarte, C. M.: Comparative analyses in aquatic microbial ecology: how far do they go?, FEMS Microbiol. Ecol., 31, 99-106, 2000.

Grob, C., Ulloa, O., Li, W. K. W., Alarcón, G., Fukasawa, M., and Watanabe, S.: Picoplankton abundance and biomass across the eastern South Pacific Ocean along latitude $32.5^{\circ} \mathrm{S}$, Mar. Ecol. Prog. Ser., 332, 53-62, 2007.

Gundersen, K., Heldal, M., Norland, S., Purdie, D. A., and Knap, A. H.: Elemental C, N, and P cell content of individual bacteria collected at the Bermuda Atlantic Time-series Study (BATS) site, Limnol. Oceanogr., 47, 1525-1530, 2002.

Huot, Y., Babin, M., Bruyant, F., Grob, C., Twardowski, M. S., and Claustre, H.: Does chlorophyll $a$ provide the best index of phytoplankton biomass for primary productivity studies?, Biogeosciences Discuss., 4, 707-745, 2007, http://www.biogeosciences-discuss.net/4/707/2007/.

Kirchman, D. L.: Uptake and regeneration of inorganic nutrients by marine heterotrophic bacteria, in: Microbial ecology of the oceans, edited by: Kirchman, D. L., Wiley-Liss, NewYork, 261288, 2000.

Landry, M. R., Brown, S. L., Neveux, J., Dupouy, C., Blanchot, J., Christensen, S., and Bidigare, R. R.: Phytoplankton growth and microzooplankton grazing in high-nutrient, low-chlorophyll waters of the equatorial Pacific: Community and taxon-specific rate assessments from pigment and flow cytometric analyses, J. Geophys. Res., 108, 8142-8156, 2003.

Le Quéré, C., Harrison, S. P., Prentice, I. C., Buitenhuis, E. T., Aumont, O., Bopp, L., Claustre, H., Cunha, L. C. D., Geider, R., Giraud, X., Klaas, C., Kohfeld, K. E., Legendre, L., Manizza, M., Platt, T., Rivkin, R. B., Sathyendranath, S., Uitz, J., Watson, A. J., and Wolf-Gladrow, D.: Ecosystem dynamics based on plankton functional types for global ocean biogeochemistry models, Global Change Biol., 11, 2016-2040, 2005.

Li, W. K. W., Zohary, T., Yacobi, Y. Z., and Wood, A. M.: Ultraphytoplankton in the eastern Mediterranean Sea: Towards deriving phytoplankton biomass from flow cytometric measurements of abundance fluorescence and light scatter, Mar. Ecol. Prog. Ser., 102, 79-87, 1993.

Li, W. K. W.: Primary production of prochlorophytes, cyanobacteria, and eucaryotic ultraphytoplankton: Measurements from flow cytometric sorting, Limnol. Oceanogr., 39, 169-175, 1994.

Li, W. K. W.: Composition of ultraphytoplankton in the Central North Atlantic, Mar. Ecol. Prog. Ser., 122, 1-8, 1995.

Li, W. K. W.: Plankton Populations and Communities, in: Marine Macroecology, edited by: Witman, J. and Kaustuv, R., University of Chicago Press, in press, 2007.

Loisel, H. and Morel, A.: Light scattering and chlorophyll concentration in case 1 waters: A reexamination, Limnol. Oceanogr., 43, 847-858, 1998.

Mackey, D. J., Blanchot, J., Higgins, H. W., and Neveux, J.: Phytoplankton abundances and community structure in the equatorial Pacific, Deep Sea Res. II, 49, 2561-2582, 2002. 
Marie, D., Partensky, F., Simon, N., Guillou, L., and Vaulot, D.: Flow cytometry analysis of marine picoplankton, in: Living Colors: Protocols in Flow Cytometry and Cell sorting, edited by: Diamond, R. A. and DeMaggio, S., p. 421-454, 2000.

Moon van der Staay, S. Y., Wachter, R. D., and Vaulot, D.: Oceanic $18 \mathrm{~S}$ rDNA sequences from picoplankton reveal unsuspected eukaryotic diversity, Nature, 409, 607-610, 2001.

Moore, L. R., Post, A. F., Rocap, G., and Chisholm, S. W.: Utilization of different nitrogen sources by the marine cyanobacteria Prochlorococcus and Synechococcus, Limnol. Oceanogr., 47, 989-996, 2002.

Morel, A. and Ahn, Y.-H.: Optics of heterotrophic nanoflagellates and ciliates: A tentative assessment of their scattering role in oceanic waters compared to those of bacterial and algal cells, J. Mar. Res., 49, 177-202, 1991.

Morel, A., Ahn, Y.-W., Partensky, F., Vaulot, D., and Claustre, H.: Prochlorococcus and Synechococcus: a compartive study of their size, pigmentation and related optical properties, J. Mar. Res., 51, 617-649, 1993.

Morel, A., Gentili, B., Claustre, H., Babin, M., Bricaud, A., Ras, J., and Tièche, F.: Optical properties of the "clearest" natural waters, Limnol. Oceanogr., 52, 217-229, 2007.

Moutin, T., Karl, D. M., Duhamel, S., Rimmelin, P., Raimbault, P., Van Mooy, B. A. S., and Claustre, H.: Phosphate availability and the ultimate control of new nitrogen input by nitrogen fixation in the tropical Pacific Ocean, Biogeosciences Discuss., 4, $2407-$ 2440, 2007, http://www.biogeosciences-discuss.net/4/2407/2007/

Not, F., Valentin, K., Romari, K., Lovejoy, C., Massana, R., Töbe, K., Vaulot, D., and Medlin, L. K.: Picobiliphytes: A Marine Picoplanktonic Algal Group with Unknown Affinities to Other Eukaryotes, Science, 315, 253-255, 2007.

Oubelkheir, K., Claustre, H., and Babin, A. S.: Bio-optical and biogeochemical properties of different trophic regimes in oceanic waters, Limnol. Oceanogr., 50, 1795-1809, 2005.

Preisendorfer, R. W.: Application of radiative transfer theory to light measurements in the sea, Monogr., 10, 11-30, Int Union Geod Geophys, Paris, 1961.

Raimbault, P., Garcia, N., and Cerutti, F.: Distribution of inorganic and organic nutrients in the South Pacific Ocean - evidence for long-term accumulation of organic matter in nitrogen-depleted waters, Biogeosciences Discuss., 4, 3041-3087, 2007, http://www.biogeosciences-discuss.net/4/3041/2007/.

Ras, J., Claustre, H., and Uitz, J.: Spatial variability of phytoplankton pigment distributions in the Subtropical South Pacific Ocean: comparison between in situ and predicted data, Biogeosciences Discuss., 4, 3409-3451, 2007, http://www.biogeosciences-discuss.net/4/3409/2007/.

Raven, J. A., Finkel, Z. V., and Irwin, A. J.: Picophytoplankton: bottom-up and top-down controls on ecology and evolution, Vie Milieu, 55, 209-215, 2005.

Richardson, T. L. and Jackson, G. A.: Small Phytoplankton and Carbon Export from the Surface Ocean, Science, 315, 838-840, 2007.
Shalapyonok, A., Olson, R. J., and Shalapyonok, L. S.: Arabian Sea phytoplankton during Southwest and Northeast Monsoons 1995: composition, size structure and biomass from individual cell properties measured by flow cytometry, Deep-Sea Res. Part II, 48, 1231-1261, 2001.

Sherr, E. B., Sherr, B. F., and Wheeler, P. A.: Distribution of coccoid cyanobacteria and small eukaryotic phytoplankton in the upwelling ecosystem off the Oregon coast during 2001 and 2002, Deep Sea Res. II, 52, 317-330, 2005.

Sokal, R. R. and Rohlf, F. J.: Biometry the principles and practice of statistics in biological research, W. H. Freeman and Company, New York, 1994.

Stramski, D., Shalapyonok, A., and Reynolds, R.: Optical characterization of the oceanic unicellular cyanobacterium Synechococcus grown under a day-night cycle in natural irradiance, J. Geophys. Res., 100, 13 295-13 307, 1995.

Stramski, D., Reynolds, R. A., Babin, M., Kaczmarek, S., Lewis, M. R., Röttgers, R., Sciandra, A., Stramska, M., Twardowski, M. S., and Claustre, H.: Relationships between the surface concentration of particulate organic carbon and optical properties in the eastern South Pacific and eastern Atlantic Oceans, Biogeosciences Discuss., 4, 3453-3530, 2007, http://www.biogeosciences-discuss.net/4/3453/2007/.

Ulloa, O., Sathyendranath, S., Platt, T., and Quiñones, R. A.: Light scattering by marine heterotrophic bacteria, J. Geophys. Res., 97, 9619-9629, 1992.

Van de Hulst, H. C.: Light scattering by small particles, Wiley, New York, 1957.

Vaulot, D.: CYTOPC: Processing software for flow cytometric data, Signal and Noise, 2, 8, 1989.

Vaulot, D. and Marie, D.: Diel variability of photosynthetic picoplankton in the equatorial Pacific, J. Geophys. Res., 104(C2), 3297-3310, 1999.

Veldhuis, M. J. W. and Kraay, G. W.: Phytoplankton in the subtropical Atlantic Ocean: towards a better assessment of biomass and composition, Deep Sea Res. I, 51, 507-530, 2004.

Veldhuis, M. J. W., Timmermans, K. R., Croot, P., and Wagt, B. V. D.: Picophytoplankton; a comparative study of their biochemical composition and photosynthetic properties, J. Sea Res., 53, 7-24, 2005.

Waterbury, J. B., Watson, S. W., Guillard, R. R. L., and Brand, L. E.: Widespread occurrence of a unicellular, marine planktonic, cyanobacterium, Nature, 277, 293-294, 1979.

Worden, A. Z., Nolan, J. K., and Palenik, B.: Assessing the dynamics and ecology of marine picophytoplankton: The importance of the eukaryotic component, Limnol. Oceanogr., 49, 168-179, 2004.

Zubkov, M. V., Sleigh, M. A., Burkill, P. H., and Leakey, R. J. G.: Picoplankton community structure on the Atlantic Meridional Transect: a comparison between seasons, Prog. Oceanogr., 45, 369-386, 2000 